\title{
Genetic control of functional traits related to photosynthesis and water use efficiency in Pinus pinaster Ait. drought response: integration of genome annotation, allele association and QTL detection for candidate gene identification
}

Marina de Miguel 1,2, José-Antonio Cabezas ${ }^{1,2}$, Nuria de María ${ }^{1,2}$, David Sánchez-Gómez ${ }^{1}$, María-Ángeles Guevara ${ }^{1,2}$, María-Dolores Vélez ${ }^{1,2}$, Enrique Sáez-Laguna ${ }^{1,2}$, Luis-Manuel Díaz ${ }^{1,2}$, Jose-Antonio Mancha', María-Carmen Barbero ${ }^{1,2}$, Carmen Collada ${ }^{2,3}$, Carmen Díaz-Sala ${ }^{4}$ Ismael Aranda ${ }^{1}$ and María-Teresa Cervera ${ }^{1,2^{*}}$

\begin{abstract}
Background: Understanding molecular mechanisms that control photosynthesis and water use efficiency in response to drought is crucial for plant species from dry areas. This study aimed to identify QTL for these traits in a Mediterranean conifer and tested their stability under drought.

Results: High density linkage maps for Pinus pinaster were used in the detection of QTL for photosynthesis and water use efficiency at three water irrigation regimes. A total of 28 significant and 27 suggestive QTL were found. QTL detected for photochemical traits accounted for the higher percentage of phenotypic variance. Functional annotation of genes within the QTL suggested 58 candidate genes for the analyzed traits. Allele association analysis in selected candidate genes showed three SNPs located in a MYB transcription factor that were significantly associated with efficiency of energy capture by open PSII reaction centers and specific leaf area.

Conclusions: The integration of QTL mapping of functional traits, genome annotation and allele association yielded several candidate genes involved with molecular control of photosynthesis and water use efficiency in response to drought in a conifer species. The results obtained highlight the importance of maintaining the integrity of the photochemical machinery in $P$. pinaster drought response.
\end{abstract}

Keywords: Candidate gene, Drought, Genome annotation, Photochemistry, Photosynthesis, Pinus pinaster, QTL, Water use efficiency

\section{Background}

Drought resistance is crucial for growth and survival of species living in water scarce environments [1]. Unraveling the molecular mechanisms that control functional traits, such as photosynthesis and water use efficiency in response to drought, is especially relevant in view of its implication in survival, growth and biomass production.

\footnotetext{
*Correspondence: cervera@inia.es

'Departamento de Ecología y Genética Forestal, INIA-CIFOR. Ctra, de La Coruña Km 7.5, 28040 Madrid, Spain

Unidad Mixta de Genómica y Ecofisiología Forestal, INIA/UPM, Madrid, Spain Full list of author information is available at the end of the article
}

However, carbon uptake in response to drought is a complex process with many mechanisms acting in coordination in final $\mathrm{CO}_{2}$ fixation [2]. From stomatal and mesophyll resistances to diffusion of $\mathrm{CO}_{2}$ to biochemical processes within chloroplast, complex mechanisms are involved in net carbon fixation [2-5]. The functional bases that control carbon uptake under water stress have been largely studied [6,7], but less information is available about its genetic regulation.

Complex functional trait dissection can be achieved through two approaches: association studies and QTL (Quantitative Trait Loci) mapping [8]. The resolution

\section{() Biomed Central}

(c) 2014 de Miguel et al.; licensee BioMed Central Ltd. This is an Open Access article distributed under the terms of the Creative Commons Attribution License (http://creativecommons.org/licenses/by/2.0), which permits unrestricted use, distribution, and reproduction in any medium, provided the original work is properly credited. The Creative Commons Public Domain Dedication waiver (http://creativecommons.org/publicdomain/zero/1.0/) applies to the data made available in this article, unless otherwise stated. 
power of association studies is higher than QTL mapping [9]. However, the rapid decay in linkage disequilibrium of conifers [10] makes the development of genome wide association studies in these species laborious and advocates in favor of candidate gene approaches [11].

In the past, identification of candidate genes underlying QTL was difficult due to the use of anonymous markers and limited sequences with functional information, and thus restricted the approach to model plant species [12]. Nowadays, gene-based markers are easily developed and much more functional information is available for a wide range of organisms [13-18], allowing to integrate functional annotation with QTL studies [19]. Moreover, the development and application of high throughput genotyping technologies have allowed the construction of dense genetic maps [[20-27], http://dendrome.ucdavis. $\mathrm{edu} / \mathrm{cmap} /]$. The use of highly saturated genetic maps allows to narrow down the position of loci involved in the genetic control of the targeted trait and the combination of high density gene based maps with functional annotation allows to identify positional candidate genes for these QTL $[19,28]$. Suggested candidate genes are suitable for association studies that can validate markertrait associations [29]. Therefore, identification of positional candidate genes within QTL confidence intervals, some of them with known function in other species, could be considered as a preliminary step that contributes to the detection of genes underlying traits of interest [30]. Additionally, QTL mapping allows the evaluation of the genetic basis for potential adaptation in natural populations $[31,32]$ and to extend the understanding of relationships between different morpho-functional traits [33]. The identification of the main QTL involved in drought response could be a first step to develop marker assisted selection (MAS) strategies for these traits [11].

Consequently, the detection of QTL involved in photosynthesis and water use efficiency in the context of drought response is a first attempt to understand the genetic basis regulating the expression of these traits. QTL studies on functional drought response have been largely implemented for non-forest model species [34-39]. Some of these QTL studies in crop species have recently identified genomic regions controlling photochemistry of carbon uptake $[40,41]$. Breeding programs implemented in crops have reported yield improvement associated with increased photosynthesis [42]. However, fewer QTL analyses on functional drought response of forest tree species have been performed $[11,43-46]$ and to our knowledge none of them has focused on the photochemical machinery.

QTL studies involve development of a segregant progeny for target traits, phenotypic and molecular characterization of the progeny and construction of genetic maps [47]. The power to resolve the location of a QTL is related to the size of the studied population and the mapping coverage
[48]. Additionally, forest tree species are characterized by long generation times which hinder development of backcross or three-generation pedigrees by controlled crosses. On the other hand, replication of each genotype is needed for a reliable phenotypic evaluation [49], especially when working with physiological parameters that are extremely sensible to environmental conditions [41,50,51].

Mediterranean species are particularly threatened by drought [52-54], especially in the context of climatic change predictions [55]. Pinus pinaster Ait. is an important conifer in Mediterranean region with a high ecological and socio-economical value [56-58]. Although P. pinaster shows evidence of drought adaptation [59,60], recurrent or severe drought periods can limit its growth $[61,62]$. Understanding the molecular basis of drought tolerance is of high importance for a suitable management of the available genetic resources of $P$. pinaster in conservation, afforestation or breeding programs. QTL and association studies of drought tolerance traits have been developed in several tree species, such as $P$. taeda $[23,63,64]$, Populus sp. $[19,65,66]$ or Quercus robur $[43,67]$. Several QTL and association studies in $P$. pinaster have analyzed the molecular basis of different processes related to growth or wood quality traits [68-73], terpenes [74] and serotiny [75]. However, to date only association studies based on a few potential candidate genes $[59,60]$ and one QTL study have analyzed the molecular basis of drought tolerance in P. pinaster [44].

The main objective of this work was to unravel the genetic basis of different functional parameters related to carbon uptake and water use efficiency in response to drought for P. pinaster. For this purpose a QTL analysis using vegetatively propagated genotypes in order to improve the reliability of phenotypic estimates was designed. Several specific objectives were outlined: 1) construction of dense gene-based linkage maps with functional information; 2) identification of genomic regions underlying photosynthesis and water use efficiency in response to drought through QTL analysis; and 3) identification of a set of promising candidate genes in targeted genomic regions that may be involved in the genetic regulation of photosynthesis and water use efficiency in response to drought.

\section{Methods}

\section{Plant material, experimental setup and phenotypic evaluation}

Plant material, experimental setup and phenotypic evaluation are explained in detail in de Miguel et al. [76]. Briefly, 162 seedlings from a F1 full-sib family of P. pinaster obtained from a controlled cross between a male parent (Oria6) from Oria, a natural population from South-East Spain ( $\left.37^{\circ} 31^{\prime} \mathrm{N} 2^{\circ} 21^{\prime} \mathrm{W}\right)$ and a female parent (Gal1056) from a breeding program established in 
Pontevedra, North-West Spain $\left(42^{\circ} 10\right.$ 'N $\left.8^{\circ} 30^{\prime} \mathrm{W}\right)$, were vegetatively replicated and established in an incomplete block design in a greenhouse at Instituto Nacional de Investigación y Tecnología Agraria y Alimentaria (INIA). Phenotypic evaluations were conducted on the 103 clones for which at least three ramets were obtained. For phenotypic characterization three time-points of measurement were carried out starting in October 2009. During the $1^{\text {st }}$ time-point, plants were watered close to full holding capacity. Then, watering was withdrawn and during the $2^{\text {nd }}$ time-point of measurement plants were left 7 days without watering. The final third batch of measurements was carried out after plants have been 14 days without watering. Net photosynthetic rate $\left(\mathrm{A}_{\mathrm{n}}, \mu \mathrm{mol} \mathrm{CO}_{2} \mathrm{~m}^{-2} \mathrm{~s}^{-1}\right)$, stomatal conductance to water vapour $\left(\mathrm{g}_{\mathrm{sw}}, \mathrm{molH}_{2} \mathrm{Om}^{-2} \mathrm{~s}^{-1}\right)$, intrinsic water use efficiency (WUE $\mathrm{W}_{\mathrm{i}}, \mu \mathrm{mol} \quad \mathrm{CO}_{2}$ $\mathrm{molH}_{2} \mathrm{O}^{-1}$ ), specific leaf area (SLA, $\left.\mathrm{m}^{2} \mathrm{Kg}^{-1}\right)$, maximum efficiency of photosystem II under light conditions $\left(\mathrm{F}_{\mathrm{v}}{ }^{\prime} \mathrm{F}_{\mathrm{m}}{ }^{\prime}\right)$ and quantum yield $\left(\Phi_{\mathrm{PSII}}\right)$ were measured for all plants. Chlorophyll fluorescence parameters were measured following the procedure described in Cano et al. [6].

In the $1^{\text {st }}$ time-point of measurement four adult needles were collected for each plant, dried and ground into a fine homogeneous powder. Carbon isotope composition was measured with a PDZ Europa ANCA-GSL elemental analyzer interfaced to a PDZ Europa 20-20 continuous flow isotope ratio mass spectrometer (Sercon Ltd., Cheshire, UK) at Stable Isotope Facility UC Davis, California, USA. The isotopic composition of ${ }^{13} \mathrm{C}(\%)$ was expressed as [77]:

$$
\delta^{13} C=\frac{R_{s}-R_{b}}{R_{b} * 1000}
$$

Where $R_{s}$ and $R_{b}$ refer to the ${ }^{13} C /{ }^{12} C$ ratio in the sample and in the Pee Dee Belemnite standard, respectively.

Broad-sense heritability estimates and genetic correlations were calculated for the analyzed traits according to de Miguel et al. [76].

\section{DNA extraction and marker genotyping}

The mapping progeny was genotyped with nuclear microsatellites (single sequence repeats, nSSR), selective amplification of microsatellite polymorphic loci (SAMPL) and single nucleotide polymorphism (SNP) markers. Different DNA extraction methods were used in needles: a modified protocol from Dellaporta et al. [78] for nSSRs, SAMPLs and SNP array D (detailed below); the commercial kit Invisorb DNA plants HTS 96 kit (Invitek $\mathrm{GmbH}$, Berlin, Germany) for SNP arrays A and C (detailed below) and the commercial kit DNeasy Plant mini kit (Qiagen, Düsseldorf, Germany) for SNP array B (detailed below).
A total of twenty nine primer pairs designed for amplification of nSSR loci in P. pinaster and P. taeda $[79,80]$ were tested for their segregations in the mapping population and both progenitors and six progeny individuals were genotyped. The whole mapping progeny was then genotyped only for polymorphic microsatellite loci. PCRs were performed in $10 \mu \mathrm{l}$ containing $10 \mathrm{ng}$ of DNA, $1 \mathrm{x}$ PCR reaction buffer (Invitrogen, Grand Island, NY, USA), $250 \mu \mathrm{M}$ of each dNTP (Invitrogen, Grand Island, NY, USA), $0.25 \mathrm{U}$ Taq polymerase (Invitrogen, Grand Island, $\mathrm{NY}$, USA), $4 \mathrm{mM} \mathrm{MgCl}_{2}$ (Invitrogen, Grand Island, NY, USA) except for A6D12 where $2 \mathrm{mM} \mathrm{MgCl} 2$ was used, $0.2 \mu \mathrm{M}$ of forward primer and $0.2 \mu \mathrm{M}$ of reverse primer labeled on its $5^{\prime}$ end with IRD800. The PCR profile used was $94^{\circ} \mathrm{C} 4 \mathrm{~min}, 2$ cycles of $94^{\circ} \mathrm{C} 45 \mathrm{~s}, 60^{\circ} \mathrm{C} 45 \mathrm{~s}, 72^{\circ} \mathrm{C}$ $45 \mathrm{~s}, 18$ touchdown cycles of $94^{\circ} \mathrm{C} 45 \mathrm{~s}, 59.5^{\circ} \mathrm{C} 45 \mathrm{~s}$ $\left(-0.5^{\circ} \mathrm{C} /\right.$ cycle $), 72^{\circ} \mathrm{C} 45 \mathrm{~s}, 20$ cycles $94^{\circ} \mathrm{C} 30 \mathrm{~s}, 50^{\circ} \mathrm{C} 30 \mathrm{~s}$, $72^{\circ} \mathrm{C} 45 \mathrm{~s}$ and final extension at $72^{\circ} \mathrm{C} 5 \mathrm{~min}$. PCR reactions were carried out with a Perkin-Elmer GenAmp 9700 thermal cycler (Perkin Elmer Inc., Waltham, Massachusetts, USA). Amplified products were separated on denaturing gels containing $6 \%(\mathrm{w} / \mathrm{v})$ acrylamide/bisacrylamide (19:3), $7 \mathrm{M}$ urea and $1 \times \mathrm{TBE}$ and visualized in a 4300 DNA Analyzer (LI-COR Biosciences, Lincoln, NE, USA). Fragments were scored visually as codominant markers.

SAMPL genotyping was performed as in de Miguel et al. [81] with several modifications. Preamplification was carried out using EcoRI + A / MseI + C primer combination. In order to identify the most informative selective primer combinations (those with a higher number of informative polymorphic fragments) different primer combinations were tested using DNA from the progenitors and 6 offspring. A total of five CATA/EcoRI and three GATA/EcoRI primer combinations were used for the selective amplification. The whole mapping progeny was then genotyped for the eight selected SAMPL primer combinations. Primers CATA and GATA were IRDye 700 and IRDye 800 5'end labeled, respectively. Samples were loaded into denaturing gels containing 16\% (w/v) Long Ranger ${ }^{\circ} 50 \%(\mathrm{w} / \mathrm{v})$ Gel Solution (Lonza, Basel, Switzerland), $7 \mathrm{M}$ urea and $1 \mathrm{x}$ TBE. Fragment detection was carried out on a 4300 DNA Analyzer (LI-COR Biosciences, Lincoln, NE, USA). Each gel was visually scored twice independently by two different people.

In this study, four SNP genotyping assays were used, three of which were Golden Gate assays (Illumina Inc., San Diego, CA, USA): SNP arrays A and C, which were two different 1,536 BeadArray ${ }^{\mathrm{mm}}$ experiments; and SNP array B, which was a 384 BeadXpress ${ }^{\circ}$. The SNP array D was a $12 \mathrm{~K}$ Infinium assay (Illumina Inc., San Diego, CA, USA). SNP arrays $B$ and $C$ were used to genotype the whole mapping progeny, whereas A and D could be used only on 83 and 70 progeny individuals, respectively. SNP 
array B was developed including many of the SNPs targeted in array A [82] and 14 additional SNPs from candidate genes for drought resistance [59] in order to complete the information for a set of genes of special interest (see de Miguel et al. [81] for further details). When the same SNP was successfully genotyped in both assays only the data of SNP array B was used because of the higher number of individuals genotyped in this assay. SNP array $C$ was designed using a $P$. pinaster gene catalog obtained from 454 sequencing of cDNA libraries constructed with different tissues from 9 siblings of the mapping progeny submitted to different growing conditions (i.e. drought stress versus control plants; E SáezLaguna et al., unpublished). The genotyping of SNP array $\mathrm{C}$ was developed at CNIO, Madrid, Spain. Finally, SNP array D contained 10,593 SNPs identified from unigene set "PineContig_v2" of P. pinaster [20]. The four genotyping assays were carried out according to the manufacturer's instructions (Illumina Inc., San Diego, CA, USA) and SNPs clusters revised manually with Illumina Genome Studio v.1.9.4 software with a GenCall score cutoff of 0.15 . SNP clusters were modified manually to refine cluster positions when necessary. For the SNP array D (12 K Infinium) SNPs with Gen-Train values lower than 0.25 were discarded, with values between 0.25 and 0.5 were manually scored and with values higher than 0.5 were automatically scored.

\section{Construction of dense linkage maps}

For the construction of two genetic maps, one for each progenitor (Gal1056 and Oria6), the "two-way-pseudotestcross" mapping strategy was applied [83]. The consensus map for the cross, combining markers informative for both parents, was also developed $(\mathrm{GxO})$. Linkage analyses and map estimations were performed using the regression mapping algorithm implemented in the software JoinMap ${ }^{\circ} \mathrm{v} 4.1$ [84] with the CP population type and using a recombination fraction $<0.35$ and a LOD $>$ 3 as mapping parameters. Map distances were calculated using Kosambi mapping function [85]. For map building a goodness-of-fit jump threshold of 5 was established. JoinMap suggests three genetic maps with increasing number of markers (map1, map2 and map3). In map2, new markers were added because more pair wise data were available but statistical support is the same as in map1. In map3, the remaining loci were added by increasing the goodness-of fit jump threshold. In these cases map2 was kept for further analyses. Mean $x^{2}$ contribution to the goodness of fit and number of double recombinants were inspected in order to remove not reliably positioned markers from the estimated maps. When a pair of markers was considered identical based on the lack of recombination between them, only one of the markers was selected for mapping (see
Additional file 1). Segregation ratios were tested using $x^{2}$ test $(\mathrm{p} \leq 0.01)$ after Bonferroni correction. Framework maps for Gal1056, Oria6 and GxO were also built. For this purpose, only the most informative markers with very reliable positions and inter marker distance of circa $10 \mathrm{cM}$ were kept. Total genome length was calculated as the sum of all mapped marker intervals. Estimated genome length was determined from the partial linkage data according to Hulbert et al. [86] modified by Chakravarti et al. [87] (Method 3). To estimate genome length using framework maps, a minimum LOD score of three was chosen. Observed map coverage was calculated as the ratio of total genome length to estimated genome length. To estimate the number of different mapped genes a BlastN was performed between gene sequences contained in the different SNP genotyping arrays. Sequences with a percentage of identity higher than $98 \%$ were considered the same gene. To test whether the mapped genes were evenly distributed between linkage groups $x^{2}$ tests $(\mathrm{p}<0.05)$ were performed by comparing observed and estimated numbers of genes per linkage group (LG). The expected number of genes for each LG was obtained by multiplying the ratio size of LG to total genome length by the total number of mapped genes. Linkage maps were compared with previously developed P. pinaster maps $[20,81,82]$ based on common SNPs and SSRs.

\section{QTL mapping}

In order to avoid errors in marker order that may have some impact on the precision and accuracy of QTL placement, QTL analyses were performed using the framework linkage maps. QTL detection was carried out using the regression algorithm implemented in the software MapQTL ${ }^{\bullet}$ v6.0 [88]. Interval mapping was applied followed by multiple QTL mapping (MQM) when more than one QTL was found for a trait. Analyses were performed using a mapping step size of one. The thresholds (95\% and 99\% confidence) for QTL significance were determined using a chromosome and genome wide permutation test with 10,000 iterations. Support intervals for the detected QTL were estimated based on the observed decrease of LOD value in one and two units. QTL identified with only the $95 \%$ significance at chromosome level were considered as suggestive of putative QTL. Each detected QTL received an identification name indicating the measured trait, the time-point of measurement, the linkage group (LG) and the map ("f" and " $\mathrm{m}$ " for female and male parents respectively and "i" for consensus map) where the QTL was detected.

\section{Candidate genes search}

Functional annotation for gene based markers of SNP arrays A, B and D were described by Chancerel et al. 
[20,82]. Functional annotation for SNP array C was obtained with Blast2GO software [89]. For high-scoring segment pair (HSP) a restrictive $\mathrm{E}^{-20}$ e-value was chosen finding in a Blastx search against a set of 88,516 reference proteins from UniProt (http://www.uniprot.org/). In order to update annotation information for the sequences of the four SNP arrays that mapped to the QTL, a second round of annotation was performed using Blast2GO software with a restrictive $E^{-25}$ e-value for HSP, and annotation was completed with InterPro (http://www.ebi.ac.uk/interpro/) and Kyoto Encyclopedia of Genes and Genomes (KEGG, http://www.genome.jp/ $\mathrm{kegg} /$ ) searches. For those genes within the significant QTL confidence intervals $( \pm 2$ LOD), functional annotations were queried to identify functional relationship between the positional candidate genes and each analyzed trait. In order to cover all mapped genes, QTL confidence intervals in framework maps were extrapolated to maps with all the mapped markers.

Association between phenotypes and alleles at candidate loci was further studied by ANOVA using the traits as dependent variables and the SNP genotypes as factors. Thereof nineteen traits (seven different traits measured at three water irrigation regimes, except $\delta^{13} \mathrm{C}$ measured only at $1^{\text {st }}$ time-point) and 73 SNPs located in 58 identified candidate genes were inspected. False discovery rate
(FDR) was calculated using the package qvalue. Association analyses were carried out in $\mathrm{R}$ version 2.15.2 ( $\mathrm{R}$ Development Core Team, 2012).

\section{Results}

\section{Phenotypic evaluation}

Descriptive statistics of all analyzed traits are shown in Table 1. Almost all traits showed a close to normal distribution with low levels of skewness and kurtosis. Although normal distribution is an assumption in interval mapping, this method and MQM are quiet robust against deviations from normality [88]. Water stress produced a decrease in mean values for almost all variables except for $\mathrm{WUE}_{\mathrm{i}}$ and SLA that showed higher and very similar mean values, respectively, for the three time-points of measurement. Coefficients of variation were progressively higher with the imposition of drought stress being $g_{s w}$ the trait that showed the higher coefficient of variation in the $3^{\text {rd }}$ time-point of measurement.

Phenotypic correlations between the studied traits are presented in Table 2. $A_{n}$ was correlated with $g_{s w}$ and with chlorophyll fluorescence parameters $\left(\mathrm{F}_{\mathrm{v}}{ }^{\prime} \mathrm{F}_{\mathrm{m}}{ }^{\prime}\right.$ and $\left.\Phi_{\mathrm{PSII}}\right)$. The magnitude of the correlation coefficients was very similar for the $1^{\text {st }}$ time-point of measurement. However, under drought stress $\mathrm{A}_{\mathrm{n}}$ showed a higher correlation coefficient with chlorophyll fluorescence parameters than with

Table 1 Descriptive statistics of measured traits in the $F_{1}$ full sib family Gal1056xOria6 $(n=103)$

\begin{tabular}{|c|c|c|c|c|c|c|c|}
\hline Trait & Time-point & Mean \pm SD & Range & CV(\%) & Skewness & Kurtosis & p-value \\
\hline \multirow[t]{3}{*}{$A_{n}$} & 1 & $10.8 \pm 1.3$ & $7.9-15.2$ & 12.4 & 0.65 & 0.46 & 0.04 \\
\hline & 2 & $10.1 \pm 1.3$ & $6.5-12.9$ & 12.4 & -0.21 & 0.16 & 0.63 \\
\hline & 3 & $5.9 \pm 1.7$ & $1.2-9.9$ & 29.8 & -0.18 & -0.3 & 0.67 \\
\hline \multirow[t]{3}{*}{$g_{s w}$} & 1 & $0.21 \pm 0.03$ & $0.141-0.301$ & 15.9 & 0.47 & 0.09 & 0.04 \\
\hline & 2 & $0.146 \pm 0.03$ & $0.068-0.222$ & 22.6 & 0.06 & -0.44 & 0.57 \\
\hline & 3 & $0.07 \pm 0.03$ & $0.01-0.198$ & 45.7 & 0.71 & 1.28 & 0.02 \\
\hline \multirow[t]{3}{*}{$W_{U} E_{i}$} & 1 & $54.7 \pm 9.8$ & $32.5-81.8$ & 17.9 & 0.7 & 0.52 & 0.003 \\
\hline & 2 & $79.9 \pm 16.4$ & 41.2-130.1 & 20.6 & 0.4 & 0.21 & 0.38 \\
\hline & 3 & $100.4 \pm 27.8$ & $44.8-179.4$ & 27.7 & 0.52 & 0.34 & 0.05 \\
\hline$\delta^{13} \mathrm{C}$ & 1 & $-29.6 \pm 0.64$ & $-31.1 /-28$ & 2.2 & 0.003 & -0.09 & 0.92 \\
\hline \multirow[t]{3}{*}{ SLA } & 1 & $7.3 \pm 0.7$ & 5.8-10.4 & 9.6 & 1.16 & 3.26 & $<0.001$ \\
\hline & 2 & $6.7 \pm 0.6$ & $5.6-8.6$ & 9.4 & 0.55 & -0.005 & 0.03 \\
\hline & 3 & $6.6 \pm 0.6$ & $5.3-8.8$ & 9.5 & 0.68 & 0.94 & 0.02 \\
\hline \multirow[t]{3}{*}{$F_{v}{ }^{\prime} F_{m}{ }^{\prime}$} & 1 & $0.618 \pm 0.03$ & $0.496-0.684$ & 5.3 & -0.71 & 1.16 & 0.02 \\
\hline & 2 & $0.575 \pm 0.04$ & $0.48-0.688$ & 7.5 & -0.32 & -0.26 & 0.04 \\
\hline & 3 & $0.468 \pm 0.04$ & $0.361-0.591$ & 8.5 & 0.14 & 0.17 & 0.94 \\
\hline \multirow[t]{3}{*}{$\Phi_{P S I I}$} & 1 & $0.21 \pm 0.02$ & $0.157-0.252$ & 9.9 & -0.44 & 0.03 & 0.09 \\
\hline & 2 & $0.213 \pm 0.03$ & $0.153-0.276$ & 11.8 & 0.15 & -0.43 & 0.63 \\
\hline & 3 & $0.16 \pm 0.02$ & $0.096-0.223$ & 15.5 & -0.008 & -0.05 & 0.99 \\
\hline
\end{tabular}

$\mathrm{A}_{\mathrm{n}}=$ net photosynthetic rate $\left(\mu \mathrm{mol} \mathrm{CO} \mathrm{m}^{-2} \mathrm{~s}^{-1}\right) ; \mathrm{g}_{\mathrm{sw}}=$ stomatal conductance to water vapour $\left(\mathrm{molH}_{2} \mathrm{Om}^{-2} \mathrm{~s}^{-1}\right) ; \mathrm{WUE}_{\mathrm{i}}=$ intrinsic water use efficiency $\left(\mu \mathrm{mol} \mathrm{CO}_{2}\right.$ $\left.\mathrm{molH}_{2} \mathrm{O}^{-1}\right) ; \delta^{13} \mathrm{C}=$ isotopic composition of ${ }^{13} \mathrm{C}(\%) ; \mathrm{SLA}=$ specific leaf area $\left(\mathrm{m}^{2} \mathrm{Kg}^{-1}\right) ; \mathrm{F}_{\mathrm{v}}{ }^{\prime} \mathrm{F}_{\mathrm{m}}{ }^{\prime}=$ maximum efficiency of PSII under light conditions; $\Phi_{\mathrm{PSII}}=$ quantum yield. Time-points of measurements correspond with: 1, well watered plants; 2, seven days without irrigation; 3, fourteen days without irrigation. SD stands for standard deviation and CV for coefficient of variation. p-values were obtained from Shapiro- test to check normality. 
Table 2 Pearson correlation coefficients and statistical significance for measured traits in the $F_{1}$ full sib family Gal1056xOria6 $(n=103)$

\begin{tabular}{|c|c|c|c|c|c|c|c|}
\hline Time-point & Trait & $g_{s w}$ & WUE $_{i}$ & $\delta^{13} \mathrm{C}$ & SLA & $F_{v}^{\prime} F_{m}^{\prime}$ & $\Phi_{\text {PSII }}$ \\
\hline \multirow[t]{6}{*}{1} & $A_{n}$ & $0.42^{* *}$ & $0.36^{* *}$ & n.s & $0.23^{*}$ & $0.47^{* *}$ & $0.54^{* *}$ \\
\hline & $g_{s w}$ & & $-0.61^{* *}$ & $-0.51^{* *}$ & $0.37^{* *}$ & $0.24^{*}$ & n.s \\
\hline & WUE $E_{i}$ & & & $0.49^{* *}$ & n.s & n.s & $0.37^{* *}$ \\
\hline & $\delta^{13} \mathrm{C}$ & & & & $0.34^{* *}$ & n.s & $0.31^{* *}$ \\
\hline & SLA & & & & & $0.21^{*}$ & n.s \\
\hline & $F_{v}{ }^{\prime} F_{m}{ }^{\prime}$ & & & & & & $0.31^{* *}$ \\
\hline \multirow[t]{5}{*}{2} & $A_{n}$ & $0.52^{* *}$ & n.s & - & n.s & $0.62^{* *}$ & $0.58^{* *}$ \\
\hline & $g_{s w}$ & & $-0.8^{* *}$ & - & $0.29^{* *}$ & $0.5^{* *}$ & $0.2^{*}$ \\
\hline & WUE $_{\mathrm{i}}$ & & & - & $0.21^{*}$ & $0.24^{*}$ & n.s \\
\hline & SLA & & & - & & $0.22^{*}$ & n.s \\
\hline & $F_{v}{ }^{\prime} F_{m}{ }^{\prime}$ & & & - & & & $0.39^{* *}$ \\
\hline \multirow[t]{5}{*}{3} & $A_{n}$ & $0.57^{* *}$ & n.s & - & n.s & $0.82^{* *}$ & $0.77^{* *}$ \\
\hline & $g_{s w}$ & & $-0.65^{* *}$ & - & n.s & $0.49^{* *}$ & $0.27^{* *}$ \\
\hline & $W^{\prime} E_{i}$ & & & - & n.s & n.s & n.s \\
\hline & SLA & & & - & & n.s & n.s \\
\hline & $F_{v}{ }^{\prime} F_{m}{ }^{\prime}$ & & & - & & & $0.73^{* *}$ \\
\hline
\end{tabular}

$\mathrm{A}_{\mathrm{n}}=$ net photosynthetic rate $\left(\mu \mathrm{mol} \mathrm{CO}_{2} \mathrm{~m}^{-2} \mathrm{~s}^{-1}\right) ; \mathrm{g}_{\mathrm{sw}}=$ stomatal conductance to water vapour $\left(\mathrm{molH}_{2} \mathrm{Om}^{-2} \mathrm{~s}^{-1}\right) ; \mathrm{WUE}_{\mathrm{i}}=$ intrinsic water use efficiency $\left(\mu \mathrm{mol} \mathrm{CO} \mathrm{CO}_{2}\right.$ $\left.\mathrm{molH}_{2} \mathrm{O}^{-1}\right) ; \delta^{13} \mathrm{C}=$ isotopic composition of ${ }^{13} \mathrm{C}(\%)$; $\mathrm{SLA}=$ specific leaf area $\left(\mathrm{m}^{2} \mathrm{Kg}^{-1}\right) ; \mathrm{F}_{\mathrm{v}}{ }^{\prime} \mathrm{F}_{\mathrm{m}}{ }^{\prime}=$ maximum efficiency of PSII under light conditions; $\Phi_{\mathrm{PSII}}=$ quantum yield. Time-points of measurements correspond with: 1, well watered plants; 2 , seven days without irrigation; 3 , fourteen days without irrigation ${ }^{*} \mathrm{p}<0.05,{ }^{* *} \mathrm{p}<0.01,{ }^{* * *} \mathrm{p}<0.001$.

$\mathrm{g}_{\mathrm{sw}}$. Besides, $\mathrm{A}_{\mathrm{n}}$ and chlorophyll fluorescence parameters showed a tight genetic correlation (see Additional file 2). For $\mathrm{WUE}_{\mathrm{i}}$ and $\delta^{13} \mathrm{C}$, a significant phenotypic (Table 2) and broad sense genetic correlation (see Additional file 2) was found. Both traits had higher phenotypic correlation coefficients with $g_{s w}$ than with $A_{n}$. SLA was moderately correlated with $\mathrm{A}_{\mathrm{n}}, \mathrm{g}_{\mathrm{sw}}, \mathrm{WUE}_{\mathrm{i}}$ and $\delta^{13} \mathrm{C}$ for the $1^{\text {st }}$ and $2^{\text {nd }}$ time-points of measurement (Table 2). Broad sense heritability estimates for the analyzed traits are presented in Additional file 3. All of them presented moderate to low values of heritability being the higher estimates for $\mathrm{g}_{\mathrm{sw}}, \mathrm{WUE}_{\mathrm{i}}$ and $\delta^{13} \mathrm{C}$.

\section{Highly saturated linkage maps}

For Gal1056, Oria6 and consensus map, 17, 16 and 13 linkage groups (LG) were obtained, respectively (Table 3). The three constructed genetic linkage maps had in total 2,107 markers representing 1,314 mapped genes (Table 3). Genes were evenly distributed between linkage groups ( $x^{2}$ test $\mathrm{p}>0.05$ for the three linkage maps). Map coverage was $65-100 \%$ and average distance between two adjacent markers was smaller than $2 \mathrm{cM}$ (Table 3 ). The vast majority of markers with distorted segregations were discarded because of insufficient linkage information to be mapped (Table 3). Out of the six distorted markers, five mapped in the first 10 and 20 cM of LG 5 in Oria6 and consensus maps, respectively (see Additional files 4 and 5).

Through comparisons between both parental maps, as well as with previously developed maps for $P$. pinaster $[20,81,82]$ based on 654 common markers, 12 groups could be identified for the three maps, which is in agreement with the haploid number of chromosomes for the species. Common markers among the different genetic maps compared mapped always in the same homologous LG excepting three markers (see Additional file 6): contigs FN696780 and AL749831 that mapped in LG 9 and LG 4 in Chancerel et al. [20] and in LG 7 and LG 9 in this study, respectively (see Additional files 4 and 5); contig CT577280 that mapped in LG 7 and LG 4 in the two different maps obtained in Chancerel et al. [20] while in Gal1056 and the consensus map it was mapped in LG 4.

For the $82 \%$ and $86 \%$ of contigs with more than one mapped SNP, they mapped at less than $1 \mathrm{cM}$ in Gal1056 and Oria6 respectively. There was a significant exception for contig BX249015 that had one SNP mapped in LG 5 (BX249015-204) in Gal1056, Oria6 and the consensus map and the other SNP mapped in LG 8 (BX249015289) in Oria6 and the consensus map (see Additional files 4 and 5), whereas this contig was mapped in LG 5 in Chancerel et al. [20].

The consensus linkage map is available at Dendrome (http://dendrome.ucdavis.edu/cmap/).

\section{QTL detection}

Of the 55 detected QTL (Table 4, Figures 1 and 2), 28 were highly significant QTL, whereas the remaining 27 could be considered as suggestive or putative QTL. QTL were detected for all traits but the higher number of QTL were detected for $\mathrm{F}_{\mathrm{v}}{ }^{\prime} \mathrm{F}_{\mathrm{m}}$ ' and $\Phi_{\mathrm{PSII}}$ (Table 4, Figures 1 and 2). The total phenotypic variance explained for a single QTL ranged from 4.6\% ( $\left.\mathrm{WUE}_{\mathrm{i}}\right)$ to $20.9 \%\left(\mathrm{~F}_{\mathrm{v}}{ }^{\prime} \mathrm{F}_{\mathrm{m}}{ }^{\prime}\right)$. The higher percentage of total phenotypic variance explained by all the QTL detected for a trait in a timepoint of measurement was $44 \%\left(\mathrm{~F}_{\mathrm{v}}{ }^{\prime} \mathrm{F}_{\mathrm{m}}{ }^{\prime}\right)$.

Consequently, four QTL hotspots could be identified in LG 5, LG 6, LG 7 and LG 12 (Table 4, Figures 1 and 2) due to the co-localization of QTL for different traits (Figures 1 and 2): SLA co-localized with $\mathrm{g}_{\mathrm{sw}}$ in LG 5 and LG 7; $\mathrm{F}_{\mathrm{v}}{ }^{\prime} \mathrm{F}_{\mathrm{m}}$ ' co-localized with $\mathrm{WUE}_{\mathrm{i}}$ in LG 5 and LG 12 with $\delta^{13} \mathrm{C}$ in LG 6, with $\mathrm{A}_{\mathrm{n}}$ in LG 6 and LG 12 and with $\Phi_{\text {PSII }}$ in LG 7 and LG 12. QTL for SLA, $F_{\mathrm{v}}{ }^{\prime} F_{m}$ ' and $\Phi_{\text {PSII }}$ were detected for the three time-points of measurement. Some of them co-localized in the same region, such as the identified for SLA in LG 5, LG 7 and LG 12 and for $\mathrm{F}_{\mathrm{v}}{ }^{\prime} \mathrm{F}_{\mathrm{m}}$ ' in LG 6 and LG 7. Co-localization of QTL for the same traits at different levels of water stress highlights the stability of QTL with the imposition 
Table 3 Mapping features of the two parental linkage maps (Gal1056 and Oria6) and consensus map for the cross (GxO)

\begin{tabular}{|c|c|c|c|}
\hline Mapping features & Gal1056 & Oria6 & GxO \\
\hline Total number of available markers & 1,539 & 1,574 & 2,601 \\
\hline SSRs loci & 8 & 7 & 8 \\
\hline SAMPL loci & 29 & 33 & 55 \\
\hline SNP loci & 1,502 & 1,534 & 2,538 \\
\hline Total number of distorted markers ${ }^{a}$ & $33(2.1 \%)$ & $36(2.3 \%)$ & $53(2 \%)$ \\
\hline Unlinked markers (\%) & $65(4.2 \%)$ & $78(5 \%)$ & $54(2.1 \%)$ \\
\hline Number of markers assigned to LG & 1,474 & 1,496 & 2,547 \\
\hline SSRs loci & 8 & 7 & 8 \\
\hline SAMPL loci & 21 & 25 & 54 \\
\hline SNP loci & 1,445 & 1,464 & 2,485 \\
\hline Number of positioned markers ${ }^{b}$ & $1,026(66.7 \%)$ & $1,184(75.2 \%)$ & $1,810(69.6 \%)$ \\
\hline SSR loci & $2(25 \%)$ & $3(42.9 \%)$ & $1(12.5 \%)$ \\
\hline SAMPL loci & $12(41.4 \%)$ & $12(36.4 \%)$ & $22(40 \%)$ \\
\hline SNP loci & $1,012(67.4 \%)$ & $1,169(76.2 \%)$ & $1,787(70.4 \%)$ \\
\hline Number of positioned genes ${ }^{c}$ & 685 & 792 & 1,154 \\
\hline Number of distorted positioned markers & 0 & 5 & 6 \\
\hline LG before alignments & 17 & 16 & 13 \\
\hline Groups after alignments & 12 & 12 & 12 \\
\hline Smallest LG before alignments & $24 \mathrm{cM}$ & $28.7 \mathrm{cM}$ & $39.1 \mathrm{cM}$ \\
\hline Largest LG before alignments & $141.9 \mathrm{cM}$ & $149.6 \mathrm{cM}$ & $165 \mathrm{cM}$ \\
\hline Average length $L G \pm S D$ before alignments (cM) & $87.6 \pm 42$ & $92.9 \pm 41.8$ & $128.9 \pm 31.8$ \\
\hline Smallest group after alignments & $76 \mathrm{cM}$ & 70.5 cM & $116.1 \mathrm{cM}$ \\
\hline Largest groups after alignments & $187.8 \mathrm{cM}$ & $149.6 \mathrm{cM}$ & $165 \mathrm{cM}$ \\
\hline Average length of a group \pm SD after alignments (CM) & $124.1 \pm 26.9$ & $123.9 \pm 22.3$ & $138.5 \pm 17.1$ \\
\hline Maximum distance between 2 adjacent markers & $20 \mathrm{cM}$ & $28.8 \mathrm{cM}$ & $18.3 \mathrm{cM}$ \\
\hline Average distance between 2 adjacent markers $\pm \mathrm{SD}^{d}$ & $1.92 \pm 2.7$ & $1.66 \pm 2.6$ & $1.24 \pm 1.9$ \\
\hline Observed map length (cM) & $1,488.7$ & $1,486.8$ & $1,662.3$ \\
\hline Estimated map length (cM) & $2,337.7$ & $1,479.7$ & $2,378.2$ \\
\hline Observed map coverage & $64 \%$ & $100 \%$ & $69.9 \%$ \\
\hline Estimated map coverage & $100 \%$ & $100 \%$ & $100 \%$ \\
\hline
\end{tabular}

${ }^{\mathrm{a} A t} \mathrm{p}<0.01$ after Bonferroni correction for the number of markers.

${ }^{b}$ Not positioned markers correspond to unlinked markers or markers which position could not be reliably estimated. Percentages calculated over the total number of available markers.

'Twenty one, 47 and 59 positioned contigs for Gal1056, Oria6 and GxO maps respectively, were not considered.

didentical markers whose position was the same because of the lack of recombination between them were not considered.

SD: Standard deviation.

of drought stress. QTL for $A_{n}$ could only be detected for the $2^{\text {nd }}$ and $3^{\text {rd }}$ time-point of measurement while QTL for $\mathrm{g}_{\mathrm{sw}}$ and $\mathrm{WUE}_{\mathrm{i}}$ were only detected in the $1^{\text {st }}$ and $2^{\text {nd }}$ time-point of measurement (Table 4).

\section{Candidate gene identification}

The $74 \%$ of the mapped sequences (991 out of 1,348) were annotated. Gene annotations and co-localization with the detected QTL lead to the identification of 58 positional candidate genes that could be involved in the expression of the targeted traits (see Additional file 7). Genes related with oxidative stress, ATPase family proteins or proteins of the light harvesting centers were found in the confidence intervals of QTL for net photosynthesis or chlorophyll fluorescence traits. Genes related with stomatal regulation, ABA signaling pathways or cell wall composition were found in QTL for $\mathrm{g}_{\mathrm{sw}}$ and $\mathrm{WUE}_{\mathrm{i}}$. Genes expressed under drought conditions co-localized with QTL identified in the $2^{\text {nd }}$ or $3^{\text {rd }}$ time-point of measurements but not in the first one, which could be pointing 
Table 4 Identified QTL in Gal1056, Oria6 and GxO maps

\begin{tabular}{|c|c|c|c|c|c|c|c|c|c|c|c|c|}
\hline Trait & Time-point & Map & Total var. & LG & LOD & Sig. & Var. & Add. Eff. & Position (cM) & $\mathrm{Cl}_{1 \mathrm{LOD}}(\mathrm{cM})$ & $\mathrm{Cl}_{2 \mathrm{LOD}}(\mathrm{cM})$ & QTL id \\
\hline \multirow[t]{4}{*}{$A_{n}$} & 2 & Oria6 & 23 & 4 & 2.7 & ${ }^{* *} \mathrm{Ch}$ & 10 & + & 91.4 & $77.1-107.4$ & $69.7-112.4$ & $\mathrm{~A}_{\mathrm{n}} \mathrm{S} 2 \mathrm{LG} 4 \mathrm{~m}$ \\
\hline & & & & 6 & 2 & ${ }^{*} \mathrm{Ch}$ & 7.1 & - & 18.5 & $5-44.5$ & $0-79.5$ & $A_{n} S 2 L G 6 m$ \\
\hline & & & & 9 & 2.4 & ${ }^{* *} \mathrm{Ch}$ & 8.7 & + & 61.8 & $40-79.8$ & 30-113.8 & $\mathrm{A}_{\mathrm{n}} \mathrm{S} 2 \mathrm{LG} 9 \mathrm{~m}$ \\
\hline & 3 & Oria6 & & 12 & 1.5 & ${ }^{*} \mathrm{Ch}$ & 12 & - & 30.6 & $0-41$ & $0-66.6$ & $A_{n} \_S 3 L G 12 m$ \\
\hline \multirow[t]{8}{*}{$g_{s w}$} & 1 & Gal1056 & 18.7 & 7_1 & 1.9 & ${ }^{* *} \mathrm{Ch}$ & 7.4 & + & 0.0 & $0-25$ & $0-27$ & $g_{s w}$ S1LG7_1f \\
\hline & & & & 12 & 2.1 & ${ }^{*} \mathrm{Ch}$ & 8 & + & 132.2 & 119-145.2 & $95.1-152.1$ & $g_{s w}$ S1LG12f \\
\hline & & $\mathrm{GxO}$ & 37.8 & 7 & 3.5 & ${ }^{* *} \mathrm{Ch}$ & 10.7 & & 37.5 & $27-47$ & $5-65$ & $g_{s w} S 1 L G 7 i$ \\
\hline & & & & 10 & 4.1 & ${ }^{* *} \mathrm{Ch}$ & 12.5 & & 16.1 & $5-40$ & $5-55$ & $g_{\mathrm{sw}} \mathrm{S1LG10i}$ \\
\hline & & & & 12 & 3.9 & ${ }^{* *} \mathrm{Ch}$ & 12 & & 114.5 & $103.1-125.5$ & $90-131.6$ & $g_{s w} S 1 L G 12 i$ \\
\hline & 2 & Gal1056 & & 5 & 2.4 & ${ }^{* *} \mathrm{Ch}$ & 10.1 & + & 86.4 & $52.9-112.3$ & $36.7-121.6$ & $g_{s w} S 2 L G 5 f$ \\
\hline & & $\mathrm{GxO}$ & 24.1 & 5 & 3.9 & ${ }^{* *} \mathrm{Ch}$ & 14.4 & & 68.7 & 61.9-79.7 & 48.3-85.7 & $g_{s w} S 2 L G 5 i$ \\
\hline & & & & 11 & 2.8 & ${ }^{*} \mathrm{Ch}$ & 10 & & 50.1 & $32.6-55.1$ & $10-75$ & $\mathrm{~g}_{\mathrm{sw}} \mathrm{S} 2 \mathrm{LG} 11 \mathrm{i}$ \\
\hline \multirow[t]{5}{*}{$W U E_{i}$} & 1 & Gal1056 & 15 & 7_1 & 1.2 & ${ }^{*} \mathrm{Ch}$ & 4.7 & - & 6.0 & $0-27$ & $0-27$ & WUE $E_{i} S 1 L G 7 \_1 f$ \\
\hline & & & & 12 & 2.0 & ${ }^{*} \mathrm{Ch}$ & 7.8 & - & 132.2 & $118-141.2$ & $83.1-152.1$ & WUE $E_{i} S 1 L G 12 f$ \\
\hline & & Oria6 & & 3_2 & 1.06 & ${ }^{*} \mathrm{Ch}$ & 4.6 & + & 0 & $0-18.4$ & $0-18.4$ & WUE $E_{i}$ S1LG3_2m \\
\hline & 2 & Gal1056 & & 5 & 2.1 & ${ }^{*} \mathrm{Ch}$ & 9 & - & 103.3 & 87.4-116.3 & 13-130.6 & WUE $\mathrm{S} 2 \mathrm{LG} 5 f$ \\
\hline & & $\mathrm{GxO}$ & & 5 & 3 & ${ }^{*} \mathrm{Ch}$ & 12.7 & & 68.7 & 49.9-76.2 & $42.1-115.7$ & WUE $\mathrm{S} 2 \mathrm{LG} 5 \mathrm{i}$ \\
\hline \multirow[t]{2}{*}{$\delta^{13} \mathrm{C}$} & 1 & Gal1056 & & 6 & 2.3 & ${ }^{*} \mathrm{ch}$ & 9.7 & + & 34.3 & $22-56.4$ & $11-79.8$ & $\delta^{13} \mathrm{C} \mathrm{S1LG6f}$ \\
\hline & & $\mathrm{G} \times \mathrm{O}$ & & 6 & 3.2 & ${ }^{*} \mathrm{Ch}$ & 13.4 & & 33.2 & $21.2-45.2$ & $8-55.4$ & $\delta^{13} \mathrm{C}$ S1LG6i \\
\hline \multirow[t]{8}{*}{ SLA } & 1 & Gal1056 & 16.2 & 5 & 1.9 & ${ }^{*} \mathrm{Ch}$ & 7.5 & + & 53.4 & $29.4-86.4$ & $0-130.6$ & SLAS1LG5f \\
\hline & & & & 12 & 2.2 & ${ }^{*} \mathrm{ch}$ & 8.8 & - & 10.1 & $0-38.1$ & $0-58.2$ & SLAS1LG12f \\
\hline & & $\mathrm{GxO}$ & & 7 & 3.1 & ${ }^{*} \mathrm{Ch}$ & 13.1 & & 12.9 & $0-53.8$ & $0-76.1$ & SLAS1LG7i \\
\hline & 2 & Gal1056 & 18.6 & 5 & 2.5 & ${ }^{* *} \mathrm{Ch}$ & 9.7 & + & 46.9 & $20-72$ & $3-96.9$ & SLAS2LG5f \\
\hline & & & & 12 & 2.6 & ${ }^{* *} \mathrm{Ch}$ & 9.8 & - & 10.1 & $0-34.1$ & $0-51.1$ & SLAS2LG12f \\
\hline & 3 & Gal1056 & 16.8 & 5 & 2.5 & ${ }^{* *} \mathrm{Ch}$ & 9.7 & + & 46.9 & $17.5-55.9$ & $12-83.9$ & SLAS3LG5f \\
\hline & & & & 7_1 & 2.2 & ${ }^{* *} \mathrm{Ch}$ & 8.5 & + & 0.0 & $0-8$ & $0-25$ & SLAS3LG7_1f \\
\hline & & $\mathrm{GxO}$ & & 7 & 3.1 & ${ }^{*} \mathrm{Ch}$ & 13.1 & & 44.8 & $29.6-87.7$ & $0-101.5$ & SLAS3LG7i \\
\hline \multirow[t]{16}{*}{$F_{v} F_{m}{ }^{\prime}$} & 1 & Gal1056 & & 7_2 & 2.9 & *gw & 12.1 & - & 5.5 & $0-35$ & $0-54.4$ & $F_{v}{ }^{\prime} F_{m}{ }^{\prime S 1 L G 7 \_2 f ~}$ \\
\hline & & Oria6 & 18 & 6 & 1.9 & ${ }^{*} \mathrm{Ch}$ & 7.4 & + & 122.4 & $114.7-122.4$ & $0-122.4$ & $F_{v}^{\prime} F_{m}{ }^{\prime S} 1 L G 6 m 1$ \\
\hline & & & & 6 & 2.7 & ${ }^{* *} \mathrm{Ch}$ & 10.3 & - & 62.7 & $37.5-96.7$ & $25.5-104.7$ & $F_{v}^{\prime} F_{m}{ }^{\prime} S 1 L G 6 m 2$ \\
\hline & & $\mathrm{GxO}$ & 28.2 & 3_2 & 3.5 & ${ }^{* *} \mathrm{Ch}$ & 12 & & 0 & $0-3$ & $0-8$ & $F_{v}^{\prime} F_{m}{ }^{\prime S}$ LIG3_2i \\
\hline & & & & 7 & 3.7 & ${ }^{* *} \mathrm{Ch}$ & 12.9 & & 90.3 & $67-120$ & $40-145.3$ & $F_{v}^{\prime} F_{m}{ }^{\prime} S 1 L G 7 i$ \\
\hline & 2 & Gal1056 & 22.9 & $2 \_1$ & 1.9 & ${ }^{*} \mathrm{Ch}$ & 7 & - & 0.0 & $0-11$ & $0-100.3$ & $F_{v}^{\prime} F_{m}{ }^{\prime S} S 2 L G 2 \_1 f$ \\
\hline & & & & 5 & 2.7 & ${ }^{* *} \mathrm{Ch}$ & 10 & + & 86.5 & 71.9-99.4 & $20.5-114.4$ & $F_{v}{ }^{\prime} F_{m}{ }^{\prime} S 2 L G 5 f$ \\
\hline & & & & 12 & 2.1 & ${ }^{*} \mathrm{Ch}$ & 7.5 & + & 152.1 & $130.6-152.1$ & $75.2-152.1$ & $F_{v}^{\prime} F_{m}{ }^{\prime} S 2 L G 12 f$ \\
\hline & & Oria6 & 32.7 & $1 \_2$ & 2.6 & ${ }^{* *} \mathrm{Ch}$ & 8.2 & - & 45.1 & $30.2-66.1$ & $24.5-67.8$ & $\mathrm{~F}_{\mathrm{v}}{ }^{\prime} \mathrm{F}_{\mathrm{m}}{ }^{\prime} \mathrm{S} 2 \mathrm{LG} 1 \_2 \mathrm{~m}$ \\
\hline & & & & 3_1 & 3.3 & ${ }^{* *} \mathrm{gw}$ & 10.8 & + & 18.6 & $2-22.6$ & $0-26.6$ & $F_{v}^{\prime} F_{m}{ }^{\prime} S 2 L G 3 \_1 m$ \\
\hline & & & & 6 & 2 & ${ }^{*} \mathrm{Ch}$ & 6.4 & - & 62.7 & 38.3-85.7 & $0-101.7$ & $F_{v} F_{m}{ }^{\prime} S 2 L G 6 m$ \\
\hline & & & & 12 & 1.7 & ${ }^{*} \mathrm{Ch}$ & 5.4 & - & 30.6 & $0-41.6$ & $0-66.6$ & $F_{v}^{\prime} F_{m}^{\prime} S 2 L G 12 m$ \\
\hline & & $\mathrm{GxO}$ & 44 & 6 & 4.1 & ${ }^{* *} \mathrm{Ch}$ & 11.4 & & 59.3 & $55-77$ & $50-95$ & $F_{v}{ }^{\prime} F_{m}{ }^{\prime} S 2 L G 6 i$ \\
\hline & & & & 7 & 7 & ${ }^{* *} g w$ & 20.9 & & 54.8 & $50-66$ & $48-70$ & $F_{v}^{\prime} F_{m}{ }^{\prime} S 2 L G 7 i$ \\
\hline & & & & 9 & 3.6 & ${ }^{*} \mathrm{ch}$ & 9.6 & & 71.3 & $65-80$ & $60-85$ & $F_{v}^{\prime} F_{m}{ }^{\prime} S 2 L G 9 i$ \\
\hline & & & & 12 & 4.7 & ${ }^{* *} \mathrm{gw}$ & 13.2 & & 83.3 & $80-95$ & $77-110$ & $F_{v}{ }^{\prime} F_{m}{ }^{\prime} S 2 L G 12 i$ \\
\hline
\end{tabular}


Table 4 Identified QTL in Gal1056, Oria6 and GxO maps (Continued)

\begin{tabular}{|c|c|c|c|c|c|c|c|c|c|c|c|c|}
\hline & \multirow[t]{3}{*}{3} & Oria6 & & 6 & 2.1 & ${ }^{*} \mathrm{Ch}$ & 9 & - & 34.3 & $0-43.3$ & $0-68.7$ & $F_{v}{ }^{\prime} F_{m}{ }^{\prime S} 3 L G 6 m$ \\
\hline & & $\mathrm{G} \times \mathrm{O}$ & 29.1 & 6 & 3.7 & ${ }^{* *} \mathrm{Ch}$ & 13.3 & & 54.8 & $0-80$ & $0-124.8$ & $F_{v}^{\prime} F_{m}{ }^{\prime S} 3 L G 6 i$ \\
\hline & & & & 7 & 4.5 & ${ }^{*} \mathrm{gw}$ & 15.6 & & 63.7 & 55.8-71.6 & $54.5-81.6$ & $F_{v}^{\prime} F_{m}^{\prime} S 3 L G 7 i$ \\
\hline \multirow[t]{9}{*}{$\Phi_{\text {PSII }}$} & \multirow[t]{4}{*}{1} & \multirow[t]{3}{*}{ Gal1056 } & \multirow[t]{3}{*}{20.1} & $2 \_2$ & 1.8 & ${ }^{*} \mathrm{Ch}$ & 6.8 & - & 85.2 & 69.9-95.5 & $0-95.5$ & $\Phi_{\text {PSII }}$ S1LG2_2f \\
\hline & & & & 4_1 & 2.7 & ${ }^{* *} \mathrm{Ch}$ & 10.1 & + & 3.3 & $0-22.3$ & $0-34.3$ & ФPSII S1LG4_1f \\
\hline & & & & $7 \_2$ & 1.8 & ${ }^{*} \mathrm{Ch}$ & 6.5 & - & 37.4 & $23.8-60.4$ & $0-88.8$ & $\Phi_{\text {PSII }}$ S1LG7_2f \\
\hline & & \multicolumn{2}{|l|}{ Oria6 } & 8_2 & 2.7 & ${ }^{* *} \mathrm{Ch}$ & 11.3 & - & 79 & $74.1-79$ & $60.8-79$ & $\Phi_{\text {PSII }}$ S1LG8_2m \\
\hline & 2 & \multicolumn{2}{|l|}{$\mathrm{G} \times \mathrm{O}$} & 7 & 2.9 & ${ }^{*} \mathrm{Ch}$ & 12.3 & & 37.5 & $24.6-62.8$ & $16.5-62.8$ & $\Phi_{\text {PSII }}$ S2LG7i \\
\hline & \multirow[t]{4}{*}{3} & \multicolumn{2}{|l|}{ Gal1056 } & 8 & 1.8 & ${ }^{*} \mathrm{Ch}$ & 7.8 & - & 99.6 & $78.5-110$ & $0-124.5$ & $\Phi_{\text {PSII }}$ S3LG8f \\
\hline & & \multirow[t]{2}{*}{ Oria6 } & \multirow[t]{2}{*}{15.1} & 4 & 2 & ${ }^{*} \mathrm{Ch}$ & 7.9 & + & 20.5 & $10.5-30.5$ & $0-56.5$ & ФPSII S3LG4m \\
\hline & & & & 12 & 1.9 & ${ }^{*} \mathrm{Ch}$ & 7.3 & - & 12.7 & $0-30.7$ & $0-66.5$ & $\Phi_{\text {PSII }}$ S3LG12m \\
\hline & & $\mathrm{GxO}$ & & 7 & 2.9 & ${ }^{*} \mathrm{Ch}$ & 12.2 & & 63.7 & 48.8-67.1 & $24.6-71.2$ & $\Phi_{\text {PSII }}$ S3LG7i \\
\hline
\end{tabular}

Columns stand for trait names $\left[\mathrm{A}_{\mathrm{n}}=\right.$ net photosynthetic rate $\left(\mu \mathrm{mol} \mathrm{CO}_{2} \mathrm{~m}^{-2} \mathrm{~s}^{-1}\right) ; \mathrm{g}_{\mathrm{sw}}=$ stomatal conductance to water vapour $\left(\mathrm{molH}_{2} \mathrm{Om} \mathrm{m}^{-2} \mathrm{~s}^{-1}\right) ; \mathrm{WUE}_{\mathrm{i}}=$ intrinsic water use efficiency $\left(\mu \mathrm{mol} \mathrm{CO}_{2} \mathrm{molH}_{2} \mathrm{O}^{-1}\right) ; \delta^{13} \mathrm{C}=$ isotopic composition of ${ }^{13} \mathrm{C}(\%)$; $\mathrm{SLA}=$ specific leaf area $\left(\mathrm{m}^{2} \mathrm{Kg}^{-1}\right), \mathrm{F}_{\mathrm{v}} \mathrm{F}_{\mathrm{m}}{ }^{\prime}=\mathrm{maximum}$ efficiency of PSII under light conditions; $\Phi_{\mathrm{PSII}}=$ quantum yield], time-points of measurements $\left(1^{\text {st }}\right.$ stands for well watered, $2^{\text {nd }}$ and $3^{\text {rd }}$ for seven and 14 days without watering), genetic map where the QTL was identified, total phenotypic variance explained (\%) for all detected QTL for a given trait in a given time-point of measurements, linkage group, maximum LOD score for mapped markers, level of significance $\left({ }^{*}<0.05,{ }^{* *}<0.01\right.$, ch stands for chromosome and gw for genome wide level), total phenotypic variance explained for each QTL (\%), sign of the additive effect, position of the marker with the maximum LOD score, one LOD confidence interval, two LOD confidence interval and QTL identification name.

out the induced drought functional response of $P$. pinaster. Other remarkable co-localizations were found for two QTL for SLA with an enzyme involved in auxin biosynthesis, or between a QTL for $\delta^{13} \mathrm{C}$ and a member of the aquaporin family (see Additional file 7 for a detailed list of candidate genes). ANOVA test developed for the 73 tested SNPs in candidate genes resulted in 43 significant associations with at least one of the analyzed traits (data not shown). After corrections using the false discovery rate estimated, only three SNPs of the gene MYB1 (m746, m747 and $\mathrm{m} 751)$ remained significantly associated with $\mathrm{F}_{\mathrm{v}}{ }^{\prime} \mathrm{F}_{\mathrm{m}}$ ' measured in the $1^{\text {st }}$ time-point (well watered plants) and SLA measured in the $3^{\text {rd }}$ time-point (14 days without watering; Figure 3). SNP m746 was located in an intron but $\mathrm{m} 747$ and m751 were located in exon regions. The base substitution in SNP m747 was a non-synonymous change between a threonine (when a cytosine is present) and an isoleucine (when a thymine is present) while in $\mathrm{m} 751$ was a synonymous change. SNPs m747 and m751 explained $14.4 \%$ and $12.6 \%$ of the phenotypic variance for $\mathrm{F}_{\mathrm{v}}{ }^{\prime} \mathrm{F}_{\mathrm{m}}{ }^{\prime}$ measured in the $1^{\text {st }}$ time-point and SLA measured in the $3^{\text {rd }}$ time-point respectively. SNP m746 explained 9\% of the total phenotypic variance for $\mathrm{F}_{\mathrm{v}}{ }^{\prime} \mathrm{F}_{\mathrm{m}}$ ' measured in the $1^{\text {st }}$ time-point.

\section{Discussion}

\section{Highly saturated linkage maps}

Combining different types of markers three highly dense linkage maps were constructed. They include more than 1,000 genes scattered throughout the genome of $P$. pinaster and distributed in 12 groups that match the chromosome number of the species. The aforementioned highly saturated maps, with less than $2 \mathrm{cM}$ mean distance between markers, are in the range of recently published linkage maps for other conifer species $[20,22,24,27,51]$. Estimated map length was higher in the female than in the male parent. Differences in genome length between parental maps are usually found in conifer species [90-93] and it may be a consequence of differences in the recombination rate between parental trees $[94,95]$.

The accuracy of the SNP genotyping assays previously proved $[20,82]$ has been confirmed in this study by genes with more than one SNP that mapped in almost all cases within a distance lower than $1 \mathrm{cM}$. The single exception of contig BX249015 could be attributed to the existence of two paralogous genes for this sequence placed in different LGs. Indeed, high levels of synteny and colinearity were observed between female and male parental maps. The fact that four out of the five distorted markers mapped in the same region suggests that segregation distortion could be due to pre or post-zygotic selection rather than to genotyping errors.

The construction of dense genetic maps for different conifers provides additional tools for studying conifer genomes organization and evolution at a finer scale [27]. In addition, high density linkage maps can be used to position scaffolds along linkage groups contributing to the assembly of a reference genome sequence $[24,96]$. $P$. pinaster genome sequencing is currently in progress, and it should be noted that Oria6, the male progenitor of the mapping family, is the genotype from which the haploid line was selected and its DNA used as template [97]. 


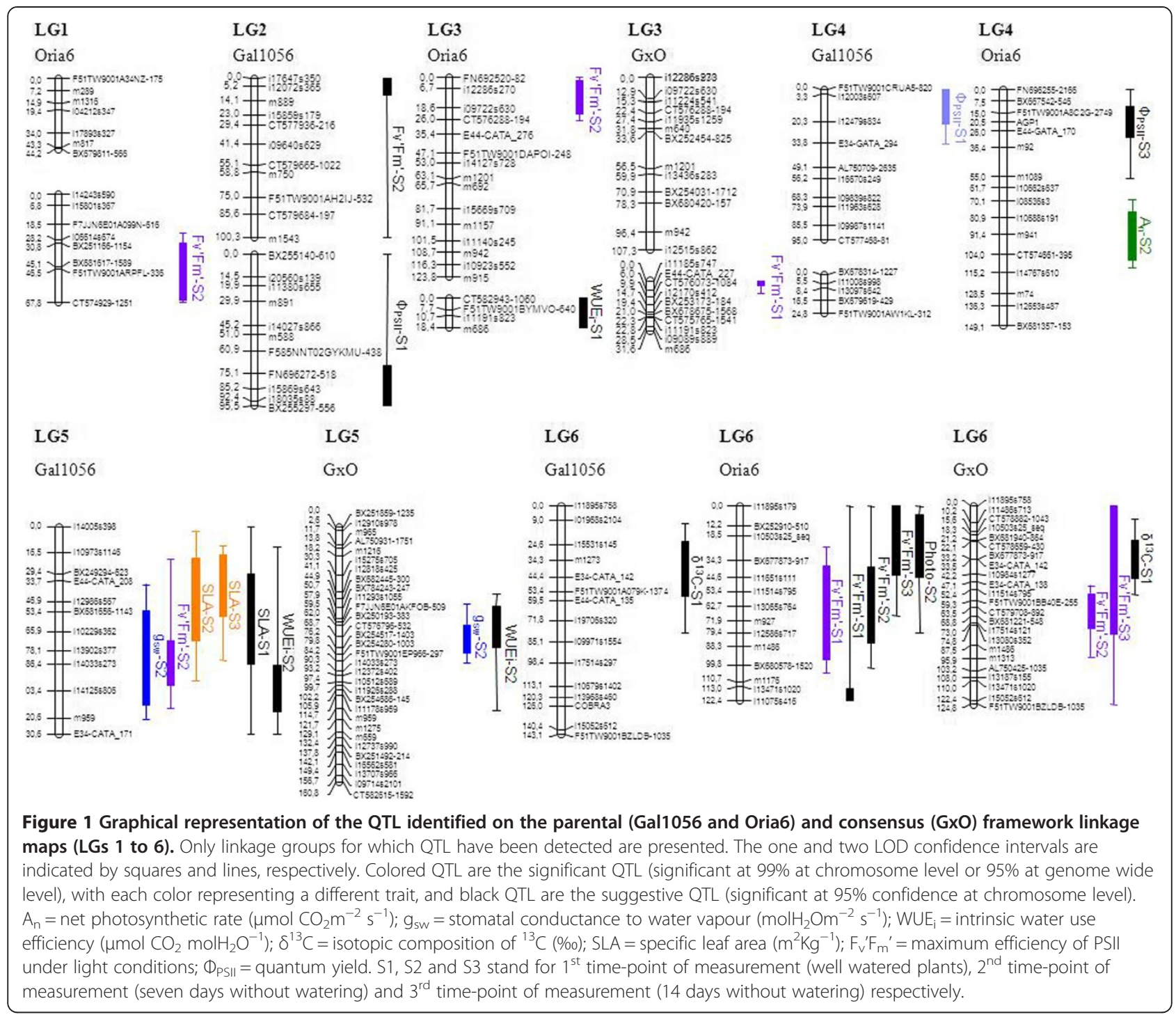

Additionally, development of dense genetic maps from individuals belonging to two Spanish natural populations (from Northwest coast and Southeast mountains) that show high levels of genetic divergence with the Spanish (from the Castilian Plateau; [81]) and French populations (from Landes and Corsica; [20]), from which segregating progenies have been previously mapped, is important to explore the genetic organization and evolution of the species. Synteny and colinearity were highly conserved when compared with 654 common markers with previous studies $[20,81,82]$. Only three discrepancies were found that supposed just a $0.46 \%$ over all the common markers analyzed: Contig CT577280 was mapped in LG 7 and LG 4 in two of three obtained maps for $P$. pinaster in Chancerel et al. [20] and it was suggested the existence of two paralogous genes for this sequence. In this study the position of CT577280 in LG 4 was confirmed. Contigs FN696780 and AL749831 mapped in LG 9 and LG 4 in Chancerel et al.
[20] and in LG 7 and LG 9 in this study respectively, which suggest also the existence of two paralogous genes for these sequences.

The high level of synteny and colinearity observed between the genetic maps developed for individuals that belong to populations with very different genetic backgrounds [98] points out the high reliability in the marker order obtained. Thus, it is possible the development of a composite genetic map for the species by integrating the genetic maps developed by de Miguel et al. [81], Chancerel et al. [20] and those obtained in this work, which is currently in progress. Parental maps are the most accurate regarding both, marker order and marker distances; since they have been constructed through separated information of the meiosis occurred in each progenitor. Accuracy is also related with the presence of genotyping errors, missing values and segregation distortion in the molecular marker data used for 


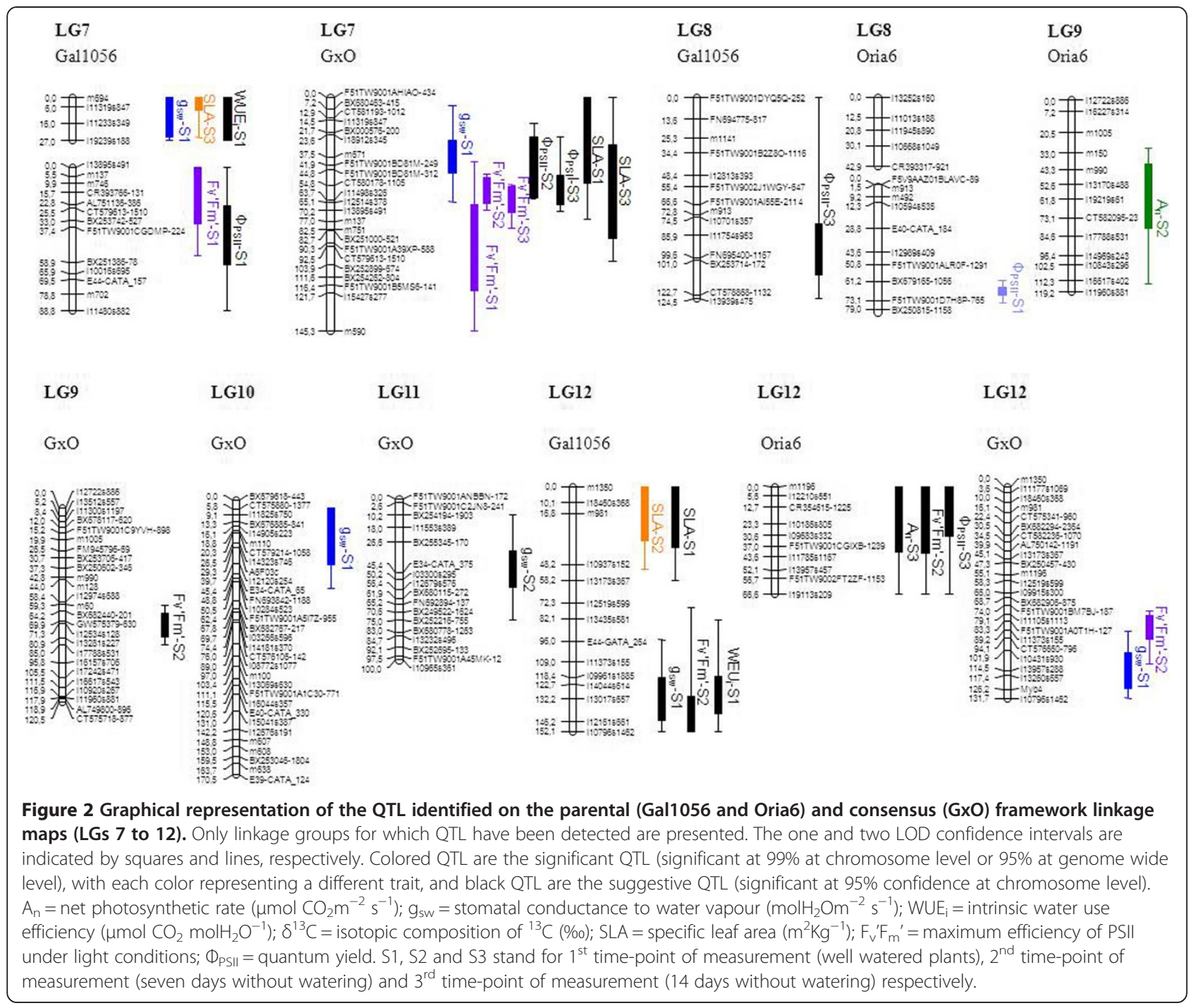

the construction of linkage maps [99]. In this study it was achieved by the thorough genotypic data integrity obtained by using highly stringent thresholds to consider SNPs for mapping. Also, the position of the SNPs genotyped in fewer individuals (SNP array D) was validated through the comparison with previously developed $P$. pinaster maps [20]. In addition, only a few distorted markers have been mapped and almost all located in a narrow region of a single linkage group (Oria6 and GxO LG 5), which points towards a probable biological origin. Even so, QTL analyses have been developed using framework linkage maps to minimize the problems that possible errors in marker order could cause.

\section{QTL detection}

One of the main goals of this work was to identify QTL for leaf functional traits related to photosynthesis and water use efficiency in response to drought. QTL analysis in forest tree species is challenging by its long generation times which hinder the development of classical mapping populations like backcross, $\mathrm{F}_{2}$ or recombinant inbred lines. In order to overcome this shortcoming alternative strategies are usually developed for QTL detection in trees, such as the two-way pseudo-testcross [83] used in this study. In this work, two parents from contrasting populations in their drought response were selected to maximize the variability of the $F_{1}$ obtained progeny, at molecular and functional levels. Although some recent QTL studies in trees worked with larger progenies [51,100,101], the 162 obtained siblings in this study are in the range or higher than other QTL analysis in trees $[31,46,69,70,102]$. On the other side, gas exchange parameters are extremely sensible to variations in the environmental conditions. To cope with the problem of environmental noise in phenotypic evaluation, different strategies have been used for QTL analysis in the literature. For example the implementation of statistical and physiological models to adjust phenotypic values for microclimatic differences $[41,50]$ or 


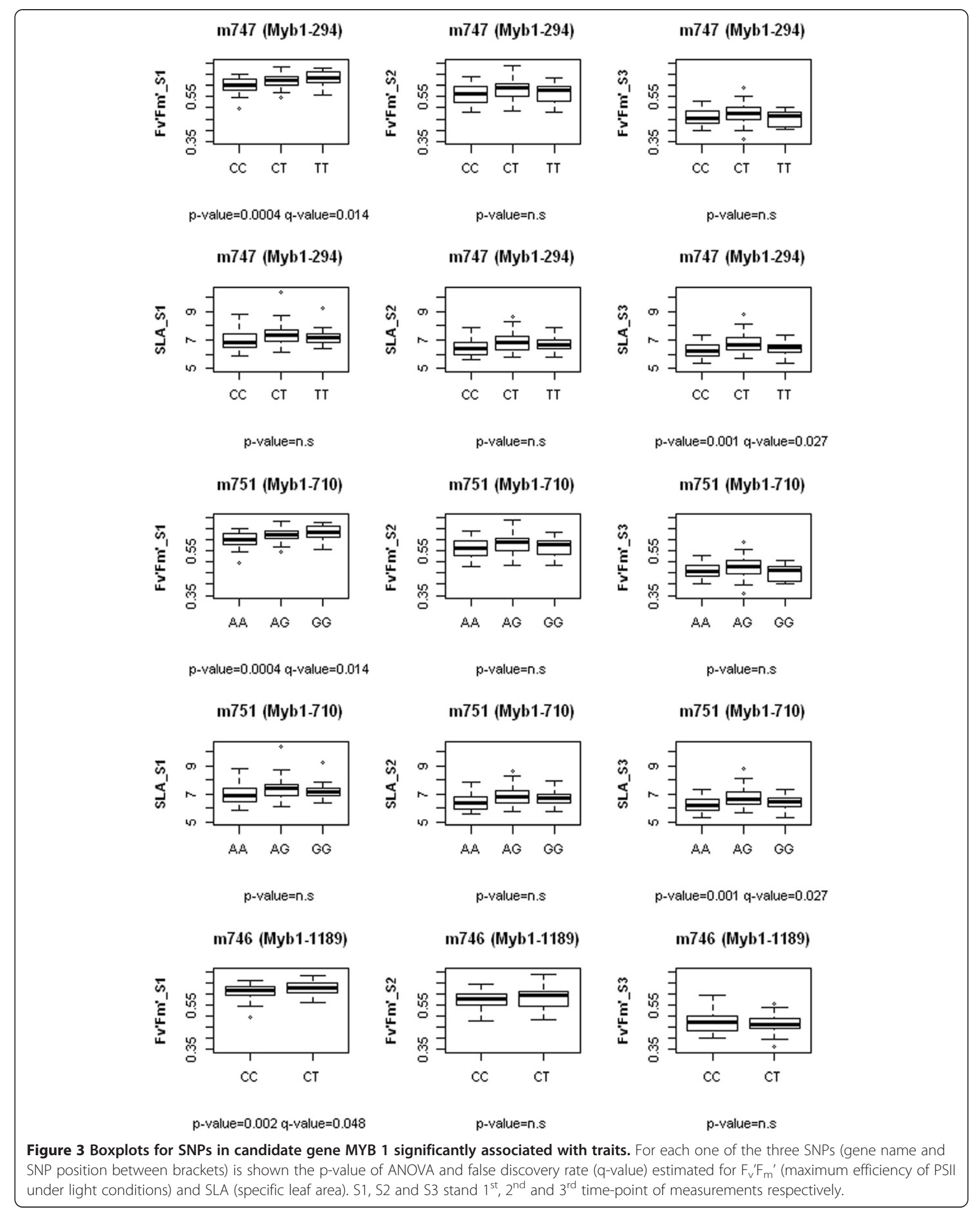


the development of inbred line populations for annual species [103,104]. In this study, four vegetative copies of each genotype were established in a completely randomized block design in a greenhouse. All these efforts allowed the identification of significant and suggestive QTL for important traits related to water use efficiency and carbon uptake in $P$. pinaster.

For all the analyzed traits several QTL were identified with moderate effects rather than a single or few QTL with large effect, as expected for complex functional traits. The only exception was $\delta^{13} \mathrm{C}$ for which only one QTL could be identified. For gas exchange parameters, the percentage of observed phenotypic variance explained when taking into account all significant QTL detected in a single trait in each time-point of measurements was in average $20 \%$. In addition, some suggestive QTL for water use efficiency estimated from different approaches have been reported, although their existence should be further tested using larger population sizes or analyzing their stability in different genetic backgrounds [105]. For chlorophyll fluorescence parameters, a large number of QTL were identified. The significant QTL detected in each time-point of measurement for $\mathrm{F}_{\mathrm{v}}{ }^{\prime} \mathrm{F}_{\mathrm{m}}$ ' explained together up to $44 \%$ of the observed phenotypic variance. The results achieved point towards a tight genetic control of photochemical traits, as previously described in crop species like maize [103,106], barley [104] or soybean [40].

For $\delta^{13} \mathrm{C}$ only one QTL was detected in LG 6, in agreement with Brendel et al. [44] that found a QTL in the same region of LG 6 for P. pinaster. No co-localization of QTL for WUE $\mathrm{W}_{\mathrm{i}}$ and $\delta^{13} \mathrm{C}$ was found in spite of the significant phenotypic and genetic correlation between both traits. In this study $\delta^{13} \mathrm{C}$ was measured only in the $1^{\text {st }}$ time-point of measurement, thus its value probably reflected the water use efficiency in well watered conditions. As the genotypes analyzed have showed high genetic variability in water use efficiency in response to drought [76], it could be expected to observe higher variation in $\delta^{13} \mathrm{C}$ in needles developed under water limiting conditions maintained in a long-lasting water stress period [107-109]. Higher variability on $\delta^{13} \mathrm{C}$ would enhance the detection of QTL for this trait and it might be possible to find other QTL as reported by Brendel et al. [44], who found four significant and four suggestive QTL. Differences in the number of detected QTL for $\delta^{13} \mathrm{C}$ between both studies could also be explained because Brendel et al. [44] measured $\delta^{13} \mathrm{C}$ in tree growth rings from 15 years-old trees while in this study $\delta^{13} \mathrm{C}$ was measured in needles of one year-old seedlings. Nevertheless, the co-localization of this QTL for $\delta^{13} \mathrm{C}$ between two genetically unrelated progenies from wide geographic origins (Landes $\mathrm{x}$ Landes versus Galicia $\mathrm{x}$ Oria) and growing under different environmental conditions supports its stability.
Interaction between QTL and environmental conditions was tested performing the QTL analyses using three different time-points of measurements corresponding to different water irrigation regimes. In general, most of the detected QTL were environment-specific, suggesting that genes are differentially activated during maritime pine drought response [110]. Nevertheless, several QTL for $\mathrm{F}_{\mathrm{v}}{ }^{\prime} \mathrm{F}_{\mathrm{m}}{ }^{\prime}, \Phi_{\mathrm{PSII}}$ and SLA were less sensitive to environmental conditions and maintained the same location with drought imposition, confirming the stability of these QTL across different levels of water stress endured by plants.

This way, four clusters of QTL were identified in LG 5, LG 6, LG 7 and LG 12. Clustering of QTL could be related with the pleiotropic effect of one or a few genes affecting different traits rather to the existence of rich gene regions, as genes were homogeneously distributed between LGs. Chancerel et al. [20] detected higher number of genes in LG 6 and LG 12 than in the other linkage groups, however the maps developed in this study could not confirm these results.

QTL for photosynthesis measured through gas exchange and chlorophyll fluorescence parameters co-localized in LG 6 and LG 12, accordingly with the high broad-sense genetic correlation found between both traits. However, additional and no co-localizing QTL were identified for these traits in other LGs, suggesting that $\mathrm{CO}_{2}$ fixation and electron transport were not entirely coupled, in agreement with $\mathrm{Gu}$ et al. [41]. Uncoupling of these two processes may be due to drought effects on stomatal conductance, biochemical alterations of carbon fixation enzymes, or photoinhibition affecting electron transport rate $[7,8]$.

Under drought stress $A_{n}$ and $g_{s w}$ showed a lower level of phenotypic correlation while the correlation coefficient between $A_{n}$ and $F_{v}{ }^{\prime} F_{m}$ ' or $\Phi_{\text {PSII }}$ increased with water stress, which suggests that under stomatal closure the differences that can be observed between genotypes in carbon fixation could be due to differences in electron transport through PSII rather than to differences in stomatal conductance, as previously observed in other species [106].

SLA showed a significant phenotypic and genetic correlation with $\mathrm{WUE}_{\mathrm{i}}$ and $\mathrm{F}_{\mathrm{v}}{ }_{\mathrm{v}} \mathrm{F}_{\mathrm{m}}{ }^{\prime}$. The identification of relationships between two traits using phenotypic correlations may not distinguish whether the traits could be causally related or simply varying in association. However, the coincidence of QTL for two traits is strong evidence that they could be functionally related [36]. QTL co-localization of SLA with $\mathrm{WUE}_{\mathrm{i}}$ and $\mathrm{F}_{\mathrm{v}}{ }^{\prime} \mathrm{F}_{\mathrm{m}}{ }^{\prime}$ was found in LG 5 and LG 7 pointing towards a strong interrelationship between SLA, $\mathrm{WUE}_{\mathrm{i}}$ and $\mathrm{F}_{\mathrm{v}}{ }^{\prime} \mathrm{F}_{\mathrm{m}}$ '. The aforementioned co-localization could indicate that plants with lower SLA are more efficient in water use but had a lower efficiency of electron transport through photosystem 
II that could be explained because of the higher importance of $g_{s w}$ over $A_{n}$ in determining $W_{U}$ in this species [76,111-113].

Most of the detected QTL were found only in one of the two progenitors. The parental trees were selected from two distant populations, showing high level of genetic differentiation, and with a different degree of drought tolerance. Oria6 came from the southeast of Spain governed by a Mediterranean climate with long, hard and frequent summer dry periods, while Gal1056 came from the northwest of Spain where Atlantic climate is present. Consequently, a higher degree of drought adaptation is expected in Oria6 than in Gal1056. Controlled crosses performed with so different parental trees in their response to drought are very useful to compare QTL identified in individuals with different genetic backgrounds.

\section{Candidate genes within QTL}

The identification of the gene or genes underlying a trait has been described as one of the greatest challenge for geneticists during this century [114]. The development of high density linkage maps using gene-based markers selected, in some cases, for their known implication in drought response allowed the identification of potential candidate genes for the quantitative multigenic traits analyzed in this study. Due to the lack of sequence annotation, a considerable number of mapped sequences showing high homology with cDNA sequences from other conifers could not be functionally inspected. Thus, some QTL with large effect had no obvious candidate genes but hold great promise to identify unknown genes underlying the corresponding processes in the future. For other QTL, positional candidate genes with known function in other species that were selected according to their functional similarity with genes involved in processes related with the studied trait were identified. A MIXTA-LIKE TRANSCRIPTION FACTOR (MYB) and a HISTONE CHAPERONE were found at 25 and $12 \mathrm{cM}$ from the LOD peak of one of the four most clearly detected QTL, $F_{\mathrm{v}}{ }^{\prime} \mathrm{F}_{\mathrm{m}}$ 'S2LG7i. MYB transcription factors are a wide group related with multiple physiological processes such as photosynthesis signaling [115]. The HISTONE CHAPERONE acts as a heat protection protein [116]. The increase of leaf temperature could be an important consequence under drought stress conditions due to reduced transpiration caused by stomatal closure. In this sense, the gene encoding the MYB transcription factor and the HISTONE CHAPERONE also co-localized with $F_{\mathrm{v}}{ }^{\prime} \mathrm{F}_{\mathrm{m}}$ 'S3LG7i, both QTL measured under water stress. Another gene of the $M Y B$ family encoding the MYB 1 transcription factor, co-localized with several QTL for $\mathrm{F}_{\mathrm{v}}{ }^{\prime} \mathrm{F}_{\mathrm{m}}$ ' and $\Phi_{\text {PSII }}$ measured in well watered conditions $\left(\mathrm{F}_{\mathrm{v}}{ }^{\prime} \mathrm{F}_{\mathrm{m}}{ }^{\prime} \mathrm{S} 1 \mathrm{LG} 7 \mathrm{i}, \mathrm{F}_{\mathrm{v}}{ }^{\prime} \mathrm{F}_{\mathrm{m}}{ }^{\prime}\right.$ S1LG7_2f, $\Phi_{\text {PSII }}$ S1LG7_2f $)$ and
SLA measured under water stress (SLAS3LG7i). In this sense, three SNPs positioned in $M Y B 1$ gene resulted in a significant association with $\mathrm{F}_{\mathrm{v}}{ }^{\prime} \mathrm{F}_{\mathrm{m}}{ }^{\prime}$ measured in the $1^{\text {st }}$ time-point of measurements (well watered plants) and SLA measured in the $3^{\text {rd }}$ time-point of measurements (14 days without watering). Lepoittevin et al. [117] found that the gene $M Y B 1$ showed complete linkage disequilibrium in $P$. pinaster over a distance of $1,304 \mathrm{bp}$. Together with their intron/exon location and base substitution types, this points towards association of SNPs m751 and m746 with target traits could be the consequence of genetic linkage with $\mathrm{m} 747$, that had higher chance to influence $\mathrm{F}_{\mathrm{v}}{ }^{\prime} \mathrm{F}_{\mathrm{m}}$ ' and SLA. The expression of MYB 1 regulates genes of the phenylalanine pathway in white spruce [118] and maritime pine [119]. Increase of isoprenoid related compounds has been described to be related with photoprotection mechanisms triggering under abiotic stresses [120]. In this respect, some of the SNPs observed for $M Y B 1$ at present could be related with enhancing maintenance of photochemistry function as higher $\mathrm{F}_{\mathrm{v}}{ }^{\prime} \mathrm{F}_{\mathrm{m}}$ ' during drought. These associations should be further validated analyzing, i.e. specific nucleotide variants in a panel of unrelated genotypes [121].

Several genes related with oxidative stress co-localized with QTL for photosynthesis under water stress conditions inferred both by gas exchange or chlorophyll fluorescence. For example, 5 -ADENYLSULFATE REDUCTASE-LIKE 4-LIKE that was implicated in the cell redox homeostasis [122], co-localized with QTL $\Phi_{\text {PSII }}$ S1LG8_2m; PROLYL 4HYDROXYLASE ALPHA SUBUNIT-LIKE PROTEIN that has oxidoreductase activity [123], co-localized with QTL $A_{n}$ S2LG9m; or CINNAMOYL- REDUCTASE 1LIKE and PEROXIREDOXIN- CHLOROPLASTIC-LIKE that are enzymes from the flavonoid and phenylpropanoid biosynthesis pathways, respectively [124], were on the confidence interval of QTL $F_{\mathrm{v}}{ }^{\prime} \mathrm{F}_{\mathrm{m}}{ }^{\prime}$ S2LG1_2m. Overall, gene annotation seems to point out to an important role of maintenance photochemical integrity machinery in the drought response of $P$. pinaster.

Several genes that have been described to be related with regulation of stomatal aperture were found in the range of QTL for $g_{s w}$ and $W_{U E}$. For example, MALATE DEHYDROGENASE catalyzes the reaction which converts malate to oxalacetate and a reduction in malate before stomatal closure was observed [125,126]. Also, PHOSPHOLIPASE C 3-LIKE is required for the control of stomatal aperture by ABA $[127,128]$. Genes encoding these enzymes co-localized with QTL $g_{s w}$ S2LG5f,

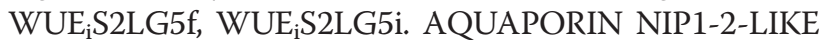
co-localized with $\delta^{13}$ CS1LG6i, which was found interesting because of the importance of aquaporins in determining the leaf water status [129] and the proved stability of this QTL. 


\section{Conclusions}

The in-depth analysis of genetic control of the $\mathrm{CO}_{2}$ fixation process in response to drought was possible after measuring different functional parameters using complementary techniques, such as gas exchange and chlorophyll fluorescence, that measure final carbon capacity uptake. The use of maritime pine replicated genotypes and a suitable experimental design have made possible to identify genetic control for functional and morphological leaf traits, measured under three water irrigation regimes as they are highly dependent on environmental conditions. Several genomic regions implicated in the genetic control of drought resistance traits have been identified. The identification of potential candidate genes leads this project a step beyond the simple detection of QTL. Nonetheless, further association studies with proposed candidate genes are needed in order to validate detected SNP marker-trait associations.

\section{Additional files}

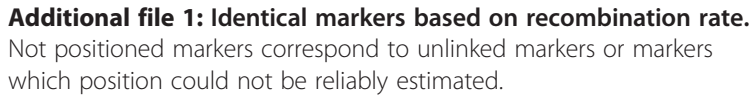

Additional file 2: Broad sense genetic correlations ( \pm standard error) between the analyzed traits.

Additional file 3: Broad sense heritability (estimate \pm standard error).

Additional file 4: Parental linkage maps for Gal1056, Oria6 and consensus map for both progenitors (GxO).

Additional file 5: Mapped markers in parental linkage maps for Gal1056, Oria6 and consensus map for both progenitors (GxO).

Additional file 6: Marker order comparison with maps obtained by Chancerel et al. [20].

Additional file 7: Candidate genes within QTL [130-180].

\section{Competing interests}

The authors declare that they have no competing interests.

\section{Authors' contributions}

MdM: SSR genotyping, phenotypic evaluation, genetic maps, QTL analysis, candidate genes search and wrote the first draft of the manuscript. JAC: genetic maps, QTL analysis and candidate genes search. NdM: SAMPL genotyping, design of SNP array C and candidate genes search. DS-G: phenotypic evaluation. MAG: SSR genotyping, SAMPL genotyping, design of SNP array $C$ and candidate genes search. MDV: SAMPL and SNP genotyping and candidate genes search. ES-L: DNA extraction and functional annotations. LD: SSR genotyping, SAMPL genotyping. JAM: phenotypic evaluation. MCB: DNA extraction, SAMPL genotyping. CC: design of SNP array $C$ and candidate genes search. CD-S: design of SNP array $C$ and candidate genes search. M-TC and IA: conceived and designed the experiments and collected funding. All authors have read and approved the final version of the manuscript.

\section{Acknowledgments}

This work was supported by the Spanish projects MAPINSEQ (AGL2009-10496; Spanish Ministry of Science and Innovation), PinCoxSeq (AGL2012-35175; Ministry of Economy and Competitiveness) and the Plant-KBBE project SUSTAINPINE (PLE2009-0016). The research leading to these results has also received funding from the European Union's Seventh Framework Programme (FP7/2007-2013) under grant agreement n² 289841 (ProCoGen). L Alté and S Ferrándiz are gratefully acknowledged for their assistance and Rose Daniels for the revision of the quality of written English.

\section{Author details}

'Departamento de Ecología y Genética Forestal, INIA-CIFOR. Ctra, de La Coruña Km 7.5, 28040 Madrid, Spain. ${ }^{2}$ Unidad Mixta de Genómica y Ecofisiología Forestal, INIA/UPM, Madrid, Spain. ${ }^{3}$ ETSIM, Departamento de Biotecnología, Ciudad Universitaria, s/n, 28040 Madrid, Spain. ${ }^{4}$ Departamento de Ciencias de la Vida, Universidad de Alcalá, Ctra. de Barcelona Km 33.6, 28871 Alcalá de Henares, Madrid, Spain.

Received: 3 October 2013 Accepted: 5 June 2014

Published: 12 June 2014

\section{References}

1. Chaves M, Davies B: Drought effects and water use efficiency: improving crop production in dry environments. Funct Plant Biol 2010, 37:3-5.

2. Pinheiro C, Chaves MM: Photosynthesis and drought: can we make metabolic connections from available data? J Exp Bot 2011, 62:869-882.

3. Jones $\mathrm{H}$ : Partitioning stomatal and non stomatal limitations to photosynthesis. Plant Cell Environ 1985, 8:95-104.

4. Foyer $\mathrm{CH}$, Neukermans J, Queval G, Noctor G, Harbinson J: Photosynthetic control of electron transport and the regulation of gene expression. J Exp Bot 2012, 63:1637-1661.

5. Cano FJ, Sánchez-Gómez D, Rodríguez-Calcerrada J, Warren CR, Gil L, Aranda I: Effects of drought on mesophyll conductance and photosynthetic limitations at different tree canopy layers. Plant Cell Environ 2013, 36:1961-1980. doi:10.1111/pce.12103.

6. Flexas J, Medrano H: Drought inhibition of photosynthesis in C3 plants: stomatal and non-stomatal limitations revisited. Ann Botany 2002, 89:183-189.

7. Flexas J, Barbour MM, Brendel O, Cabrera HM, Carriquí M, Diaz-Espejo A, Douthe C, Dreyer E, Jp JP, Gago J: Mesophyll diffusion conductance to $\mathrm{CO}_{2}$ : An unappreciated central player in photosynthesis. Plant Sci 2012, 193-194:70-84.

8. González-Martínez SC, Krutovsky KV, Neale DB: Forest-tree population genomics and adaptive evolution. New Phytol 2006, 170:227-238.

9. Neale DB, Kremer A: Forest tree genomics: growing resources and applications. Nat Rev Genet 2011, 12:111-122.

10. Neale D, Savolainen O: Association genetics of complex traits in conifers. Trends Plant Sci 2004, 9:325-330.

11. Thavamanikumar S, Southerton SG, Bossinger G, Thumma BR: Dissection of complex traits in forest trees: opportunities for marker-assisted selection. TGG 2013, 9:627-639.

12. Mochida K, Shinozaki K: Genomics and bioinformatics resources for crop improvement. Plant Cell Physiol 2010, 51:497-523.

13. Deschamps $S$, Campbell MA: Utilization of next-generation sequencing platforms in plant genomics and genetic variant discovery. Mol Breed 2010, 25:553-570.

14. Rigault P, Boyle B, Lepage P, Cooke JEK, Bousquet J, MacKay JJ: A white spruce gene catalog for conifer genome analyses. Plant Physiol 2011 157:14-28.

15. Zhou Y, Gao F, Liu R, Feng J, Li H: De novo sequencing and analysis of root transcriptome using 454 pyrosequencing to discover putative genes associated with drought tolerance in Ammopiptanthus mongolicus. BMC Genomics 2012, 13:266.

16. Qiu Q, Ma T, Hu Q, Liu B, Wu Y, Zhou H, Wang Q, Wang J, Liu J: Genomescale transcriptome analysis of the desert poplar. Populus euphratica. Tree Physiol 2011, 31:452-461

17. Li X, Wu HX, Dillon SK, Southerton SG: Generation and analysis of expressed sequence tags from six developing xylem libraries in Pinus radiata D Don. BMC Genomics 2009, 10:41.

18. Perdiguero P, Collada C, Barbero MC, Casado GG, Cervera MT, Soto A: Identification of water stress genes in Pinus pinaster Ait. by controlled progressive stress and suppression-subtractive hybridization. Plant Physiol Bioch 2012, 50:44-53.

19. Monclus R, Leplé JC, Bastien C, Bert PF, Villar M, Marron N, Brignolas F, Jorge $V$, Orléans F, Champenoux F: Integrating genome annotation and QTL position to identify candidate genes for productivity, architecture and water-use efficiency in Populus spp. BMC Plant Biol 2012, 12:173.

20. Chancerel E, Lamy J-B, Lesur I, Noirot C, Klopp C, Ehrenmann F, Boury C, Le Provost G, Label $P$, Lalanne $C$ : High-density linkage mapping in a pine tree reveals a genomic region associated with inbreeding depression and 
provides clues to the extent and distribution of meiotic recombination. BMC Biol 2013, 11:50

21. Echt C, Saha S, Krutovsky K, Wimalanathan K, Erpelding J, Liang C: An annotated genetic map of loblolly pine based on microsatellite and CDNA markers. BMC Genet 2011, 12:17.

22. Eckert AJ, Pande B, Ersoz ES, Wright MH, Rashbrook VK, Nicolet CM, Neale DB: High-throughput genotyping and mapping of single nucleotide polymorphisms in loblolly pine (Pinus taeda L.). TGG 2009, 5:225-234. 61.

23. Eckert AJ, van Heerwaarden J, Wegrzyn JL, Nelson CD, Ross-lbarra J, Gonzalez-Martinez SC, Neale D: Patterns of population structure and environmental associations to aridity across the range of loblolly pine (Pinus taeda L., Pinaceae). Genetics 2010, 185:969-982.

24. Martínez-García PJ, Stevens KA, Wegrzyn JL, Liechty J, Crepeau M, Langley $\mathrm{CH}$, Neale DB: Combination of multipoint maximum likelihood (MML) and regression mapping algorithms to construct a high-density genetic linkage map for loblolly pine (Pinus taeda L.). TGG 2013, 9:1529-1535.

25. Moriguchi Y, Ujino-Ihara T, Futamura N, Saito M, Ueno S, Matsumoto A, Tani $\mathrm{N}$, Taira H, Shinohara K, Tsumura Y: The construction of a high-density linkage map for identifying SNP markers that are tighly linked to a nuclear-recessive major gene for male sterility in Cryptomeria japonica D.Don. BMC Genomics 2012, 19:95.

26. Pavy N, Pelgas B, Beauseigle S, Blais S, Gagnon F, Gosselin I, Lamothe M, Isabel N, Bousquet J: Enhancing genetic mapping of complex genomes through the design of highly-multiplexed SNP arrays: application to the large and unsequenced genomes of white spruce and black spruce. BMC Genomics 2008, 9:21.

27. Pavy N, Pelgas B, Laroche J, Rigault P, Isabel N, Bousquet J: A spruce gene map infers ancient plant genome reshuffling and subsequent slow evolution in the gymnosperm lineage leading to extant conifers. BMC Biol 2012, 10:84.

28. Sehgal D, Rajaram V, Armstead IP, Vadez V, Yadav YP, Hash CT, Yadav RS: Integration of gene-based markers in a pearl millet genetic map for identification of candidate genes underlying drought tolerance quantitative trait loci. BMC Plant Biol 2012, 12:9.

29. Prunier J, Pelgas B, Gagnon F, Desponts M, Isabel N, Beaulieu J, Bousquet J: The genomic architecture and association genetics of adaptive characters using a candidate SNP approach in boreal black spruce. BMC Genomics 2013, 14:368.

30. Pflieger S, Lefebvre V, Causse M: The candidate gene approach in plant genetics: a review. Mol Breed 2001, 7:275-291

31. Casasoli M, Pot D, Plomion C, Monteverdi MC, Barreneche T, Lauteri M, Villani F: Identification of QTLs affecting adaptive traits in Castanea sativa Mill Plant. Cell Environ 2004, 27:1088-1101.

32. Hurme P, Sillanpaa MJ, Arjas E, Repo T, Savolainen O: Genetic basis of climatic adaptation in scots pine by bayesian quantitative trait locus analysis. Genetics 2000, 156:1309-1322.

33. Lebreton C, Lazić-Jančić V, Steed A, Pekić S, Quarrie S: Identification of QTL for drought responses in maize and their use in testing causal relationships between traits. J Exp Bot 1995, 46:853-865.

34. Whan A, Robinson N, Lakshmanan P, Schmidt S, Aitken K: A quantitative genetics approach to nitrogen use efficiency in sugarcane. Funct Plant Biol 2010, 37:448-454.

35. Price A, Courtois B: Mapping QTLs associated with drought resistance in rice: Progress, problems and prospects. Plant Growth Regul 1999, 29:123-133.

36. Thumma BR, Naidu BP, Chandra A, Cameron DF, Bahnisch LM, Liu C: Identification of causal relationships among traits related to drought resistance in Stylosanthes scabra using QTL analysis. J Exp Bot 2001, 52:203.

37. Juenger TE, Mckay JK, Hausmann N, Keurentjes JJB, Sen S, Stowe KA, Dawson TE, Simms EL, Richards JH: Identification and characterization of QTL underlying whole plant physiology in Arabidopsis thaliana: $\delta^{13} \mathrm{C}$, stomatal conductance and transpiration efficiency. Plant Cell Environ 2005, 28:697-708.

38. Specht J, Chase K, Macrander M, Graef G, Chung J, Markwell J, Germann M, Orf J, Lark K: Soybean response to water: A QTL analysis of drought tolerance. Crop Sci 2001, 41:493-509.

39. Agbicodo E, Fatokun C, Muranaka S, Visser R: Breeding drought tolerant cowpea: constraints, accomplishments, and future prospects. Euphytica 2009, 167:353-370

40. Yin Z, Meng F, Song $H, H e X, X u X, Y u$ D: Mapping quantitative trait loci associated with chlorophyll a fluorescence parameters in soybean (Glycine max (L.) Merr.). Planta 2010, 231:875-885.
41. Gu J, Yin X, Struik PC, Stomph TJ, Wang H: Using chromosome introgression lines to map quantitative trait loci for photosynthesis parameters in rice (Oryza sativa L.) leaves under drought and well-watered field conditions. J Exp Bot 2012, 63:455-469.

42. Fischer R, Edmeades GO: Breeding and cereal yield progress. Crop SC 2010, 50:85-98.

43. Brendel $\mathrm{O}$, Le Thiece D, Scotti-Saintagne C, Bodénès C, Kremer A, Guehl J-M: Quantitative trait loci controlling water use efficiency and related traits in Quercus robur L. TGG 2008, 4:263-278.

44. Brendel O, Pot D, Plomion C, Rozenberg P, Guehl JM: Genetic parameters and QTL analysis of $\delta^{13} \mathrm{C}$ and ring width in maritime pine. Plant Cell Environ 2002, 25:945-953.

45. Muchero W, Sewell MM, Ranjan P, Gunter LE, Tschaplinski TJ, Yin T, Tuskan GA: Genome anchored QTLs for biomass productivity in hybrid Populus grown under contrasting environments. PLoS One 2013, 8:e54468.

46. Freeman JS, Potts BM, Downes GM, Pilbeam D, Thavamanikumar S, Vaillancourt R: Stability of quantitative trait loci for growth and wood properties across multiple pedigrees and environments in Eucalyptus globulus. New Phytol 2013, 198:1121-1134.

47. Paterson AH, Lander ES, Hewitt JD, Peterson S, Lincoln S, Tanksley S: Resolution of quantitative traits into Mendelian factors by using a complete linkage map of restriction fragment lenght polymorphisms. Nature 1988, 335:721-726.

48. Kruglyak L, Lander ES: High-resolution genetic mapping of complex traits. Am J Hum Genet 1995, 56:1212.

49. Paran I, Zamir D: Quantitative traits in plants: beyond the QTL. Trends Genet 2003, 19:303-306.

50. Yin X, Kropff MJ, Stam P: The role of ecophysiological models in QTL analysis: the example of specific leaf area in barley. Heredity 1999, 82:415-421.

51. Pelgas B, Bousquet J, Meirmans P, Ritland K, Isabel N: QTL mapping in white spruce: gene maps and genomic regions underlying adaptive traits across pedigrees, years and environments. BMC Genomics 2011, 12:145.

52. Granda E, Camarero JJ, Gimeno TE, Martínez-Fernández J, Valladares F: Intensity and timing of warming and drought differentially affect growth patterns of co-occurring Mediterranean tree species. Eur J Forest Res 2013, 132:469-480.

53. Körner C, Sarris D, Christodoulakis D: Long-term increase in climatic dryness in the East-Mediterranean as evidenced for the island of Samos. Regional Environ Change 2005, 5:27-36.

54. Sarris D, Christodoulakis D, KÖRNER C: Recent decline in precipitation and tree growth in the eastern Mediterranean. Glob Chang Biol 2007 13:1187-1200

55. Christensen JH, Hewitson B, Busuioc A, Chen A, Gao X, Held R, Jones R, Kolli RK, Kwon W, Laprise R: Regional climate projections. Contribution of Working group I to the Fourth Assessment Report of the Intergovernmental Panel on Climate Change. In Climate Change, 2007: The Physical Science Basis. Edited by Solomon S, Qin D, Manning M, Marquis M, Averyt K, Tignor MMB, Miller HLR, Chen Z. Cambridge, UK and New York, USA: Cambridge University Press; 2007:847-940.

56. Blanco E, Casado MA, Costa M, Escribano R, García-Anton M, Génova M, Gómez-Manzaneque A, Gómez-Manzaneque F, Moreno JC, Morla C, Regato P, Sainz H: Los bosques ibéricos. Una interpretación geobotánica. 4th edition. Barcelona: Planeta; 2005.

57. Tadesse W, Nanos N, Aunon F, Arrabal C, Garcia C, Gil L, Alia R, Pardos J: Genetic improvement of resin yield from maritime pine in Spain. Forest Chem Rev 2001, 111:11.

58. INF3: Inventario Nacional Forestal. Edited by http://www.magrama.gob.es/es/ biodiversidad/temas/inventarios-nacionales/inventario-forestal-nacional/; 2007.

59. Grivet D, Sebastiani F, Alía R, Bataillon T, Torre S, Zabal-Aguirre M, Vendramin GG, González-Martínez SC: Molecular footprints of local adaptation in two Mediterranean conifers. Mol Biol Evol 2011, 28:101

60. Eveno E, Collada C, Guevara MA, Léger V, Soto A, Díaz L, Léger $P$ González-Martínez SC, Cervera MT, Plomion C, Garnier-Géré P: Contrasting patterns of selection at Pinus pinaster Ait. drought stress candidate genes as revealed by genetic differentiation analyses. Mol Biol Evol 2008, 25:417-437.

61. Martínez-Vilalata J, Piñol J: Drought-induced mortality and hydraulic architecture in pine populations of the NE Iberian Peninsula. For Ecol Manag 2002, 161:247-256. 
62. Sabaté S, Gracia CA, Sánchez A: Likely effects of climate change on growth of Quercus ilex, Pinus halepensis, Pinus pinaster, Pinus sylvestris and Fagus sylvatica forests in the Mediterranean region. For Ecol Manag 2002, 162:23-37.

63. González-Martínez SC, Huber D, Ersoz E, Davis J, Neale D: Association genetics in Pinus taeda L. II Carbon isotope discrimination. Heredity 2008, 101:19-26.

64. González-Martínez SC, Ersoz E, Brown GR, Wheeler NC, Neale DB: DNA sequence variation and selection of tag single-nucleotide polymorphisms at candidate genes for drought-stress response in Pinus taeda $\mathrm{L}$. Genetics 2006, 172:1915.

65. Street NR, Skogstrom O, Sjodin A, Tucker J, Rodriguez-Acosta M, Nilsson P, Jansson S, Taylor G: The genetics and genomics of the drought response in Populus. Plant J 2006, 48:321-341.

66. Tschaplinski TJ, Tuskan GA, Sewell MM, Gebre GM, Todd DE, Pendley CD: Phenotypic variation and quantitative trait locus identification for osmotic potential in an interspecific hybrid inbred $F_{2}$ poplar pedigree grown in contrasting environments. Tree Physiol 2006, 26:595-604.

67. Parelle J, Zapater M, Scotti-Saintagne C, Kremer A, Jolivet Y, Dreyer E, Brendel O: Quantitative trait loci of tolerance to waterlogging in a European oak (Quercus robur L.): physiological relevance and temporal effect patterns. Plant Cell Environ 2007, 30:422-434.

68. Gerber S, Lascoux M, Kremer A: Relation between protein markers and quantitative traits in maritime pine (Pinus pinaster Ait.). Silvae Genet 1997, 46:286-291.

69. Markussen $T$, Fladung $M$, Achere $V$, Favre JM, Faivre-Rampant $P$, Aragones $A$, DA Silva Pérez D, Havengt L, Ritter E: Identification of QTLs controlling growth, chemical and physical wood property traits in Pinus pinaster, Ait. Silvae Genet 2003, 52:8-15.

70. Pot D, Rodrigues J, Rozenberg P, Chantre G, Tibbits J, Cahalan C, Pichavant F, Plomion C: QTLs and candidate genes for wood properties in maritime pine (Pinus pinaster Ait.). TGG 2006, 2:10-24.

71. Plomion C, Durel CE, O'Malley DM: Genetic dissection of height in maritime pine seedlings raised under accelerated growth conditions. Theor App/ Genet 1996, 93:849-858.

72. Chagné D, Brown GR, Lalanne C, Madur D, Pot D, Neale D, Plomion C: Comparative genome and QTL mapping between maritime and loblolly pines. Mol Breed 2003, 12:185-195.

73. Lepoittevin C, Harvengt L, Plomion C, Garnier-Géré P: Association mapping for growth, straightness and wood chemistry traits in the Pinus pinaster Aquitaine breeding population. TGG 2012, 8:113-126.

74. Plomion C, Yani A, Marpeau A: Genetic determinism of delta 3-carene in maritime pine using RAPD markers. Genome 1996, 39:1123-1127.

75. Budde KB, Heuertz M, Hernández-Serrano A, Pausas JG, Vendramin GG, Verdú M, González-Martínez SC: In situ genetic association for serotiny, a fire-related trait, in Mediterranean maritime pine (Pinus pinaster). New Phytol 2014, 201:230-241. doi:10.1111/nph.12483.

76. de Miguel M, Sánchez-Gómez D, Cervera MT, Aranda I: Functional and genetic characterization of gas exchange and intrinsic water use efficiency in a full-sib family of Pinus pinaster Ait. in response to drought. Tree Physiol 2012, 32:94-103.

77. Sharp Z: Principles of stable isotope geochemistry. Upper Saddle River: NJ Pearson Education Inc.: 2007.

78. Dellaporta SL, Wood J, Hicks JB: A plant DNA minipreparation: version II. Plant Mol Biol Report 1983, 1:19-21.

79. Guevara MA, Chagné D, Almeida H, Byrnes M, Collada C, Favre JM, Harvengt $L$, Jeandroz S, Orazio C, Plomion C, Ramboer A, Rocheta M, Sebastiani F, Soto A, Vendramin GG, Cervera MT: Isolation and characterization of nuclear microsatellite loci in Pinus pinaster Ait. Mol Ecol Notes 2005, 5:57-59.

80. Chagné D: Développement de marqueurs moléculaires chez le pin maritime (Pinus pinaster Ait.) et cartographie génétique comparée des conifères. PhD. Nancy I: Nancy, France; 2004

81. de Miguel M, de María N, Guevara MA, Díaz L, Sáez-Laguna E, Sánchez Gómez D, Chancerel E, Aranda I, Collada C, Plomion C, Cabezas JA, Cervera MT: Annotated genetic linkage maps of Pinus pinaster Ait. from a Central Spain population using microsatellite and gene based markers. BMC Genomics 2012, 13:527.

82. Chancerel E, Lepoittevin C, Le Provost G, Lin Y-C, Jaramillo-Correa J, Eckert A, Wegrzyn J, Zelenika D, Boland A, Frigerio J-M, Chaumeil P, Garnier-Gere P, Boury C, Grivet D, Gonzalez-Martinez S, Rouze P, Van de Peer Y, Neale D,
Cervera M, Kremer A, Plomion C: Development and implementation of a highly-multiplexed SNP array for genetic mapping in maritime pine and comparative mapping with loblolly pine. BMC Genomics 2011, 12:368.

83. Grattapaglia D, Sederoff R: Genetic linkage maps of Eucalyptus grandis and Eucalyptus urophylla using a pseudo-testcross mapping strategy and RAPD markers. Genetics 1994, 137:1121-1137.

84. Van Ooijen JW: In Joinmap 4, software for the calculation of genetic maps in experimental populations. Edited by Kiazma BV. Wageningen; 2006.

85. Kosambi D: The estimation of map distances from recombination values. Annals Eugen 1944, 12:172-175.

86. Hulbert S, llott T, Legg E, Lincoln S, Lander E, Michelmore R: Genetic analysis of the fungus, Bremia lactucae, using restriction fragment length polymorphisms. Genetics 1988, 120:947

87. Chakravarti A, Lasher LK, Reefer JE: A maximum likelihood method for estimating genome length using genetic linkage data. Genetics 1991, 128:175-182.

88. Van Ooijen JW: MapQTL 6.0, software for the mapping of quantitative trait loci in experimental populations of diploid species. Edited by Kiazma BV. Wageningen; 2009.

89. Conesa A, Götz S, García-Gomez JM, Terol J, Talon M, Robles M: Blast2GO: a universal tool for annotation, visualization and analysis in functional genomics research. Bioinformatics 2005, 21:3674-3676.

90. Kuramoto N, Kondo T, Fujisawa Y, Nakata R, Hayashi E, Goto Y: Detection of quantitative trait loci for wood strength in Cryptomeria japonica. Can J Forest Res-Revue Canadienne De Recherche Forestiere 2000, 30:1525-1533.

91. Nikaido A, Ujino T, Iwata H, Yoshimura K, Yoshimura H, Suyama Y, Murai M, Nagasaka K, Tsumura Y: AFLP and CAPS linkage maps of Cryptomeria japonica. Theor Appl Genet 2000, 100:825-831.

92. Scotti I, Burelli A, Cattonaro F, Chagné D, Fuller J, Hedley PE, Jansson G, Lalanne C, Madur D, Neale D, Plomion C, Powell W, Troggio M, Morgante M: Analysis of the distribution of marker classes in a genetic linkage map: a case study in Norway spruce (Picea abies Karst). TGG 2005, 1:93-102.

93. Komulainen P, Brown GR, Mikkonen M, Karhu A, Garcia-Gil MR, O'Malley D, Lee $B$, Neale DB, Savolainen O: Comparing EST-based genetic maps between Pinus sylvestris and Pinus taeda. Theor Appl Genet 2003, 107:667-678.

94. Sewell MM, Sherman BK, Neale DB: A consensus map for loblolly pine (Pinus taeda L.). I. Construction and integration of individual linkage maps from two outbred three-generation pedigrees. Genetics 1999, 151:321-330.

95. Plomion C, O'Malley D: Recombination rate differences for pollen parents and seed parents in pine. Heredity 1996, 77:341-350.

96. Mackay J, Dean JFD, Plomion C, Peterson DG, Cánovas FM, Pavy N Ingvarsson PK, Savolainen O, Guevara MÁ, Fluch S, Vinceti B, Abarca D, DíazSala C, Cervera M-T: Towards decoding the conifer giga-genome. Plant Mol Biol 2012, 80:555-569.

97. Arrillaga I, Guevara M, Muñoz-Bertomeu J, Lázaro-Gimeno D, Sáez-Laguna E, Díaz L, Torralba L, Mendoza-Poudereux I, Segura J, Cervera M: Selection of haploid cell lines from megagametophyte cultures of maritime pine as a DNA source for massive sequencing of the species. Plant Cell Tiss Org Cult 2014, doi:10.1007/s11240-014-0470-z.

98. Bucci G, González-Martínez SC, Le Provost G, Plomion C, Ribeiro MM Sebastiani F, Alía R, Vendramin GG: Range-wide phylogeography and gene zones in Pinus pinaster Ait. revealed by chloroplast microsatellite markers. Molec Ecol 2007, 16:2137-2153.

99. Hackett CA, Broadfoot LB: Effects of genotyping errors, missing values and segregation distortion in molecular marker data on the construction of linkage maps. Heredity 2003, 90:33-38.

100. Ukrainetz N, Ritland K, Mansfield S: Identification of quantitative trait loci for wood quality and growth across eight full-sib coastal Douglas-fir families. TGG 2008, 4:159-170.

101. Novaes E, Osorio L, Drost DR, Miles BL, Boaventura-Novaes CRD, Benedict C, Dervinis C, Yu Q, Sykes R, Davis M, Martin TA, Peter GF, Kirst M: Quantitative genetic analysis of biomass and wood chemistry of Populus under different nitrogen levels. New Phytol 2009, 182:878-890.

102. Bartholomé J, Salmon F, Vigneron P, Bouvet J-M, Plomion C, Gion J-M: Plasticity of primary and secondary growth dynamics in Eucalyptus hybrids: a quantitative genetics and QTL mapping perspective. BMC Plant Biol 2013, 13:120.

103. Fracheboud Y, Jompuk C, Ribaut J, Stamp P, Leipner J: Genetic analysis of cold-tolerance of photosynthesis in maize. Plant Mol Biol 2004, 56:241-253. 
104. Guo P, Baum M, Varshney RK, Graner A, Grando S, Ceccarelli S: QTLs for chlorophyll and chlorophyll fluorescence parameters in barley under post-flowering drought. Euphytica 2008, 163:203-214.

105. Kearsey M, Farquhar A: QTL analysis in plants; where are we now? Heredity 1998, 80:137-142.

106. Fracheboud Y, Ribaut JM, Vargas M, Messmer R, Stamp P: Identification of quantitative trait loci for cold-tolerance of photosynthesis in maize (Zea mays L.). J Exp Bot 2002, 53:1967-1977.

107. Aranda I, Alía R, Ortega U, Dantas AK, Majada J: Intra-specific variability in biomass partitioning and carbon isotopic discrimination under moderate drought stress in seedlings from four Pinus pinaster populations. TGG 2010, 6:169-178

108. Correia I, Almeida MH, Aguiar A, Alía R, David TS, Pereira JS: Variations in growth, survival and carbon isotope composition $\left(\delta^{13} \mathrm{C}\right)$ among Pinus pinaster populations of different geographic origins. Tree Physiol 2008, 28:1545-1552.

109. Corcuera L, Gil-Pelegrin E, Notivol E: Phenotypic plasticity in Pinus pinaster delta $C^{13}$ : environment modulates genetic variation. Ann For Sci 2010, 67:812.

110. Watkinson Jl, Sioson AA, Vasquez-Robinet C, Shukla M, Kumar D, Ellis M, Heath LS, Ramakrishnan N, Chevone B, Watson LT: Photosynthetic acclimation is reflected in specific patterns of gene expression in drought-stressed loblolly pine. Plant Physiol 2003, 133:1702-1716.

111. Fernández M, Gil L, Pardos JA: Effects of water supply on gas exchange in Pinus pinaster Ait. provenances during their first growing season. Ann For Sci 2000, 57:9-16.

112. Fernandez M, Novillo C, Pardos JA: Effects of water and nutrient availability in Pinus pinaster Ait. Open pollinated families at an early age: Growth, gas exchange and water relations. New For 2006, 31:321-342.

113. Guehl J, Fort C, Ferhi A: Differential response of leaf conductance, carbon isotope discrimination and water-use efficiency to nitrogen deficiency in maritime pine and pedunculate oak plants. New Phytol 1995, 131:149-157.

114. Price AH: Believe it or not, QTLs are accurate! Trends Plant Sci 2006, $11: 213-216$

115. Saibo NJM, Lourenço T, Oliveira MM: Transcription factors and regulation of photosynthetic and related metabolism under environmental stresses. Ann Botany 2009, 103:609-623.

116. Kotak S, Larkindale J, Lee U, von Koskull-Döring P, Vierling E, Scharf K-D: Complexity of the heat stress response in plants. Curr Opin Plant Biol 2007, 10:310-316.

117. Lepoittevin C, Garnier-Gere P, Hubert F, Plomion C: Strong linkage disequilibrium and balanced selection in Pinus pinaster transcription factors putatively involved in wood formation. In Oral presentation to IUFRO-CTIA Joint Conference "Adaptation, Breeding and Conservation in the Era of Forest Tree Genomics and Environmental Change". IUFRO-CTIA: Québec City (Canada); 2008:26-28.

118. Bomal C, Duval I, Giguère I, Fortin E, Caron S, Stewart D, Boyle B, Séguin A MacKay JJ: Opposite action of R2R3-MYBs from different subgroups on key genes of the shikimate and monolignol pathways in spruce. J Exp Bot 2014, 65:495-508.

119. Craven-Bartle B, Pascual MB, Cánovas FM, Ávila C: A Myb transcription factor regulates genes of the phenylalanine pathway in maritime pine. Plant J 2013, 74:755-766.

120. Peñuelas J, Munné-Bosc S: Isoprenoids: an evolutionary pool for photoprotection. Trends Plant Sci 2005, 10:166-169.

121. Harjes CE, Rocheford TR, Bai L, Brutnell TP, Kandianis CB, Sowinski SG, Stapleton AE, Vallabhaneni R, Williams M, Wurtzel ET: Natural genetic variation in lycopene epsilon cyclase tapped for maize biofortification. science 2008, 319:330.

122. Martin MN, Tarczynski MC, Shen B, Leustek T: The role of 5 '-adenylylsulfate reductase in controlling sulfate reduction in plants. Photosynth Res 2005, 86:309-323

123. Vlad F, Spano T, Vlad D, Bou Daher F, Ouelhadj A, Kalaitzis P: Arabidopsis prolyl-hydroxylases are differentially expressed in response to hypoxia, anoxia and mechanical wounding. Physiol Plant 2007, 130:471-483.

124. Baier M, Noctor G, Foyer CH, Dietz K-J: Antisense suppression of 2-cysteine peroxiredoxin in Arabidopsis specifically enhances the activities and expression of enzymes associated with ascorbate metabolism but not glutathione metabolism. Plant Physiol 2000, 124:823-832.

125. Riccardi F, Gazeau P, de Vienne D, Zivy M: Protein changes in response to progressive water deficit in maize quantitative variation and polypeptide identification. Plant Physiol 1998, 117:1253-1263.
126. Cramer GR, Van Sluyter SC, Hopper DW, Pascovici D, Keighley T, Haynes PA: Proteomic analysis indicates massive changes in metabolism prior to the inhibition of growth and photosynthesis of grapevine (Vitis vinifera L.) in response to water deficit. BMC Plant Biol 2013, 13:49.

127. Chaves MM, Pereira JS, Maroco JP: Understanding plant responses to drought - from genes to the whole plant. Funct Plant Biol 2003, 30:239-264.

128. Hunt L, Mills LN, Pical C, Leckie CP, Aitken FL, Kopka J, Mueller-Roeber B, McAinsh MR, Hetherington AM, Gray JE: Phospholipase $C$ is required for the control of stomatal aperture by ABA. Plant J 2003, 34:47-55.

129. Prado K, Boursiac Y, Tournaire-Roux C, Monneuse J-M, Postaire O, Da Ines O, Schäffner AR, Hem S, Santoni V, Maurel C: Regulation of Arabidopsis Leaf Hydraulics Involves Light-Dependent Phosphorylation of Aquaporins in Veins. The Plant Cell Online 2013, 25:1029-1039.

130. Ajjawi I, Coku A, Froehlich JE, Yang Y, Osteryoung KW, Benning C, Last RL: A J-like protein influences fatty acid composition of chloroplast lipids in Arabidopsis. PLoS One 2011, 6:e25368.

131. Andrews M, Huizinga DH, Crowell DN: The CaaX specificities of Arabidopsis protein prenyltransferases explain era1 and $g g b$ phenotypes. BMC Plant Biol 2010, 10:118.

132. Banci L, Bertini I, Luchinat C, Turano P: Electron Transfer, Respiration, and Photosynthesis. In Biological Inorganic Chemistry: Structure and Reactivity. Edited by Bertini I, Gray H, Stiefel El, Valentine JS. USA: University Science Books; 2007:229-261.

133. Barkla BJ, Vera-Estrella R, Maldonado-Gama M, Pantoja O: Abscisic acid induction of vacuolar $\mathrm{H}+-$ ATPase activity in Mesembryanthemum crystallinum is developmentally regulated. Plant Physiol 1999, 120:811-820

134. Bazakos C, Manioudaki ME, Therios I, Voyiatzis D, Kafetzopoulos D, Awada T, Kalaitzis P: Comparative Transcriptome Analysis of Two Olive Cultivars in Response to NaCl-Stress. PLoS One 2012, 7:e42931.

135. Beligni MV, Mayfield SP: Arabidopsis thaliana mutants reveal a role for CSP41a and CSP41b, two ribosome-associated endonucleases, in chloroplast ribosomal RNA metabolism. Plant Mol Biol 2008, 67:389-401.

136. Brandt U: Proton-translocation by membrane-bound NADH: ubiquinoneoxidoreductase (complex I) through redox-gated ligand conduction. Biochim Biophys Acta 1997, 1318:79-91.

137. Bray EA: Genes commonly regulated by water-deficit stress in Arabidopsis thaliana. J Exp Bot 2004, 55:2331-2341.

138. Çakır B, Olcay AC: Molecular cloning, phylogenetic analysis, and expression profiling of a grape CMP-sialic acid transporter-like gene induced by phytohormone and abiotic stress. Gen Genom 2013, $35: 225-238$.

139. Dietz KJ, Tavakoli N, Kluge C, Mimura T, Sharma SS, Harris GC, Chardonnens AN, Golldack D: Significance of the V-type ATPase for the adaptation to stressful growth conditions and its regulation on the molecular and biochemical level. J Exp Bot 2001, 52:1969-1980.

140. Fujimoto SY, Ohta M, Usui A, Shinshi H, Ohme-Takagi M: Arabidopsis ethylene-responsive element binding factors act as transcriptional activators or repressors of GCC box-mediated gene expression. Plant Cell Online 2000, 12:393-404.

141. Golldack D, Li C, Mohan H, Probst N: Gibberellins and abscisic acid signal crosstalk: living and developing under unfavorable conditions. Plant Cell Rep 2013, 32:1007-1016.

142. Gómez J, Sanchez-Martínez D, Stiefel V, Rigau J, Puigdomenech P, Pages M: A gene induced by the plant hormone abscisic acid in response to water stress encodes a glycine-rich protein. Nature 1988, 334:262-264.

143. Goyer A, Collakova E, de la Garza RD, Quinlivan EP, Williamson J, Gregory JF, Shachar-Hill Y, Hanson AD: 5-Formyltetrahydrofolate is an inhibitory but well tolerated metabolite in Arabidopsis leaves. J Biol Chem 2005, 280:26137-26142.

144. Gross EL: Plastocyanin: Structure, Location, Diffusion and Electron Transfer Mechanisms. In Oxygenic Photosynthesis: The Light Reactions. Edited by Ort DR, Yocum CF, Heichel IF. Netherlands: Springer; 2004:413-429.

145. Guo L, Devaiah SP, Narasimhan R, Pan X, Zhang Y, Zhang W, Wang X: Cytosolic glyceraldehyde-3-phosphate dehydrogenases interact with phospholipase $D \delta$ to transduce hydrogen peroxide signals in the Arabidopsis response to stress. Plant Cell Online 2012, 24:2200-2212.

146. Ham BK, Park JM, Lee SB, Kim MJ, Lee IJ, Kim KJ, Kwon CS, Paek KH: Tobacco Tsip1, a DnaJ-Type Zn Finger Protein, Is Recruited to and Potentiates Tsi1-Mediated Transcriptional Activation. Plant Cell 2006, 18:2005-2020 
147. Hardie DG: Plant protein serine/threonine kinases: Classification and Functions. Annu Rev Plant Physiol Plant Mol Biol 1999, 50:97-131.

148. Hernández I, Van Breusegem F: Opinion on the possible role of flavonoids as energy escape valves: Novel tools for nature's Swiss army knife? Plant Sci 2010, 179:297-301.

149. Ioannidis NE, Cruz JA, Kotzabasis K, Kramer DM: Evidence That Putrescine Modulates the Higher Plant Photosynthetic Proton Circuit. PLOS One 2012, 7:e29864.

150. Janicka-Russak M: Plant plasma membrane $\mathrm{H}+-$ ATPase in adaptation of plants to abiotic stresses. In Abiotic stress response in plants - physiological, biochemical and genetic perspectives. Edited by Shanker A, Venkateswarlu B. Rijeka, Croatia: Intech; 2011:197-218.

151. Jansson S, Gustafsson P: Evolutionary conservation of the chlorophyll a/b binding proteins cDNAs encoding Type I, II and III LHC I polypeptides from the gymnosperm Scots pine. Mol Genet Genom 1991, 229:67-76.

152. Kawasaki T, Koita H, Nakatsubo T, Hasegawa K, Wakabayashi K, Takahashi H, Umemura K, Umezawa T, Shimamoto K: Cinnamoyl-CoA reductase, a key enzyme in lignin biosynthesis, is an effector of small GTPase Rac in defense signaling in rice. Proc Nat Acad Sci U S A 2006, 103:230-235.

153. Kim J, Malladi A, van lersel MW: Physiological and molecular responses to drought in Petunia: the importance of stress severity. J Exp Bot 2012, 63:6335-6345

154. Kim JS, Jung HJ, Lee HJ, Kim KA, Goh C-H, Woo Y, Oh SH, Han YS, Kang H: Glycine-rich RNA-binding protein7 affects abiotic stress responses by regulating stomata opening and closing in Arabidopsis thaliana. Plant $J$ 2008, 55:455-466.

155. Kim S, Choi HI, Ryu HJ, Park JH, Kim MD, Kim SY: ARIA, an Arabidopsis arm repeat protein interacting with a transcriptional regulator of abscisic acid-responsive gene expression, is a novel abscisic acid signaling component. Plant Physiol 2004, 136:3639-3648.

156. Kiyosue T, Yamaguchi-Shinozaki K, Shinozaki K: Cloning of cDNAs for genes that are early-responsive to dehydration stress (ERDs) in Arabidopsis thaliana L.: identification of three ERDs as HSP cognate genes. Plant Mol Biol 1994, 25:791-798.

157. Kushwaha HR, Singh AK, Sopory SK, Singla-Pareek SL, Pareek A: Genome wide expression analysis of CBS domain containing proteins in Arabidopsis thaliana (L.) Heynh and Oryza sativa L. reveals their developmental and stress regulation. BMC Genomics 2009, 10:200.

158. Li AD, Anderson LE: Expression and Characterization of Pea Chloroplastic Glyceraldehyde-3-Phosphate Dehydrogenase Composed of Only the B-Subunit. Plant Physiol 1997, 115:1201-1209.

159. Liu F, Guo J, Bai P, Duan Y, Wang X, Chen Y, Feng H, Huang L, Kang Z: Wheat TaRab7 GTPase is part of the signaling pathway in responses to stripe rust and abiotic stimuli. PLoS One 2012, 7:e37146.

160. Miao Y, Lv D, Wang P, Wang XC, Chen J, Miao C, Songa CP: An Arabidopsis glutathione peroxidase functions as both a redox transducer and a scavenger in abscisic acid and drought stress responses. Plant Cell 2006, 18:2749-2766

161. Mishra M, Das R, Pandey GK: Role of ethylene responsive factors (ERFs) in abiotic stress mediated signaling in plants. e-J BiolSci 2009, 1:133-146.

162. Munnik T, Irvine R, Musgrave A: Phospholipid signalling in plants. Biochim Biophys Acta-Lipids and Lipid Metabolism 1998, 1389:222-272.

163. Noir S, Bömer M, Takahashi N, Ishida T, Tsui TL, Balbi V, Shanahan H, Sugimoto K, Devoto A: Jasmonate controls leaf growth by repressing cell proliferation and the onset of endoreduplication while maintaining a potential stand-by mode. Plant Physiol 2013, 161:1930-1951.

164. País SM, Tellez-lñón M, Capiati DA: Serine/threonine protein phosphatases type 2A and their roles in stress signaling. Plant Signal Behav 2009, 4:1013-1015.

165. Pedone KH, Der CJ: Small GTPase. In Encyclopedia of Biological Chemistry. Edited by Lennarz WJ, Lane MD. USA: Academic Press; 2013:242-248.

166. Pichersky E, Jansson S: The Light-Harvesting Chlorophyll a/b-Binding Polypeptides and Their Genes in Angiosperm and Gymnosperm Species. In Oxygenic Photosynthesis: The Light Reactions. Edited by Ort D, Yocum C, Heichel I. Netherlands: Springer; 2004:507-521.

167. Quilliam LA: Ras Family. In Encyclopedia of Biological Chemistry. Edited by Lennarz WJ, Lane MD. London, UK: Academic Press; 2013:12-16.

168. Ribas-Carbo M, Taylor NL, Giles L, Busquets S, Finnegan PM, Day DA Lambers $H$, Medrano H, Berry JA, Flexas J: Effects of water stress on respiration in soybean leaves. Plant Physiol 2005, 139:466-473.
169. Sakamoto H, Maruyama K, Sakuma Y, Meshi T, Iwabuchi M, Shinozaki K, Yamaguchi-Shinozaki K: Arabidopsis Cys2/His2-type zinc finger proteins function as transcription repressors under drought, cold, and highsalinity stress conditions. Plant Physiol 2004, 136:2734-2746.

170. Saxena M, Bisht R, Roy SD, Sopory SK, Bhalla-Sarin N: Cloning and characterization of a mitochondrial glyoxalase II from Brassica juncea that is upregulated by $\mathrm{NaCl}, \mathrm{Zn}$, and ABA. Biochem Biophys Res Commun 2005, 336:813-819.

171. Seidel T: Structure and Regulation of Plant Vacuolar H+-ATPase. Prog Bot 2009, 70:93-126.

172. Shimazaki K, Doi M, Assmann SM, Kinoshita T: Light regulation of stomatal movement. Annu Rev Plant Biol 2007, 58:219-247.

173. Sugano S, Kaminaka H, Rybka Z, Catala R, Salinas J, Matsui K, Ohme-Takagi M, Takatsuji H: Stress-responsive zinc finger gene ZPT2-3 plays a role in drought tolerance in petunia. Plant J 2003, 36:830-841.

174. Thidholm E, Lindstrom V, Tissier C, Robinson C, Schroder W, Funk C: Novel approach reveals localization and assembly pathway of the PsbS and PsbW proteins into the photosystem II dimer. FEBS Lett 2002, 513:217-222

175. Torres GA, Gimenes MA, de Rosa VE Jr, Quecini V: Identifying water stress-response mechanisms in citrus by in silico transcriptome analysis. Genet Mol Biol 2007, 30:888-905.

176. Tovar-Méndez A, Miernyk JA, Randall DD: Regulation of pyruvate dehydrogenase complex activity in plant cells. Eur J Biochem 2003, 270:1043-1049.

177. Van Nocker S, Ludwig P: The WD-repeat protein superfamily in Arabidopsis: conservation and divergence in structure and function. BMC Genomics 2003, 4:50.

178. Wang B, Luttge U, Ratajczak R: Effects of salt treatment and osmotic stress on V-ATPase and V-PPase in leaves of the halophyte Suaeda salsa. J Exp Bot 2001, 52:2355-2365.

179. Xu C, Jing R, Mao X, Jia X, Chang X: A wheat (Triticum aestivum) protein phosphatase $2 \mathrm{~A}$ catalytic subunit gene provides enhanced drought tolerance in tobacco. Ann Bot 2007, 99:439-450

180. Yao $X$, Xiong $W, Y e T$, Wu Y: Overexpression of the aspartic protease ASPG1 gene confers drought avoidance in Arabidopsis. J Exp Bot 2012, 63:2579-2593.

doi:10.1186/1471-2164-15-464

Cite this article as: de Miguel et al:: Genetic control of functional traits related to photosynthesis and water use efficiency in Pinus pinaster Ait. drought response: integration of genome annotation, allele association and QTL detection for candidate gene identification. BMC Genomics 2014 15:464

\section{Submit your next manuscript to BioMed Central and take full advantage of:}

- Convenient online submission

- Thorough peer review

- No space constraints or color figure charges

- Immediate publication on acceptance

- Inclusion in PubMed, CAS, Scopus and Google Scholar

- Research which is freely available for redistribution 